ZECEIVED

JUL 151999

OSTI

OAK RIDGE NATIONAL LABORATORY

\title{
HRE-Pond Cryogenic Barrier Technology Demonstration: Pre- and Post-Barrier Hydrologic Assessment
}

Gerilynn R. Moline

Environmental Sciences Division

Publication No. 4832

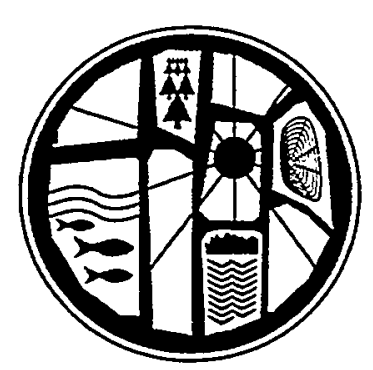

MANAGED AND OPERATED BY

LOCKHEED MARTIN ENERGY RESEARCH CORPORATION FOR THE UNTED STATES

DEPARTMENT OF ERERGY 
This report has been reproduced from the best available copy.

Reports are available to the public from the following source.

National Technical Information Service

5285 Port Royal Road

Springfield, VA 22161

Telephone 703-605-6000 (1-800-553-6847)

TDD 703-487-4639

Fax 703-605-6900

E-mail orders@ntis.fedworld.gov

Web site http://www.ntis.gov/ordering.htm

Reports are available to U.S. Department of Energy (DOE) employees, DOE contractors, Energy Technology Data Exchange (ETDE) representatives, and international Nuclear Information System (INIS) representatives from the following source.

Office of Scientific and Technical Information

P.O. Box 62

Oak Ridge, TN 37831

Telephone 423-576-8401

Fax 423-576-5728

E-mail reports@adonis.osti.gov

Web site http://www.osti.gov/products/sources.html

Reports produced after January 1,1996 , are generally available via the DOE Information Bridge.

Web site http://www.doe.gov/bridge 


\section{DISCLAIMER}

This report was prepared as an account of work sponsored by an agency of the United States Government. Neither the United States Government nor any agency thereof, nor any of their employees, make any warranty, express or implied, or assumes any legal liability or responsibility for the accuracy, completeness, or usefulness of any information,

- apparatus, product, or process disclosed, or represents that its use would not infringe privately owned rights. Reference herein to any specific commercial product, process, or service by trade name, trademark, manufacturer, or otherwise does not necessarily constitute or imply its endorsement, recommendation, or favoring by the United States Government or any agency thereof. The views and opinions of authors expressed herein do not necessarily state or reflect those of the United States Government or any agency thereof. 


\section{DISCLAIMER}

Portions of this document may be illegible in electronic image products. Images are produced from the best available original document. 
ORNL/TM-13701

ENVIRONMENTAL SCIENCES DIVISION

HRE-POND CRYOGENIC BARRUER TECHNOLOGY DEMONSTRATION: PRE- AND POST-BARRIER HYDROLOGIC ASSESSMENT

Gerilynn R. Moline

ESD Publication No. 4832

June 1999

Prepared for

U.S. Department of Energy

Office of Environmental Restoration and Waste Management under budget and reporting code EW 4010000

Prepared by

Environmental Sciences Division

OAK RIDGE NATIONAL LABORATORY

Oak Ridge, Tennessee 37831-6285 managed by

LOCKHEED MARTIN ENERGY RESEARCH CORPORATION

for the U.S. Department of Energy

under contract number DE-AC05-96OR22464 


\section{CONTENTS}

EXECUTIVE SUMMARY

Page

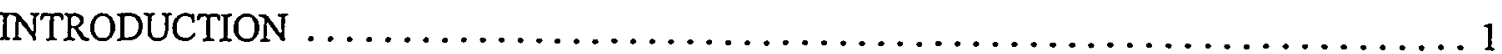

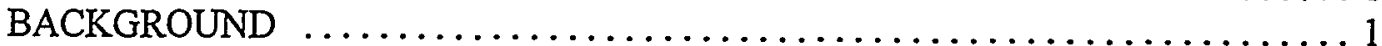

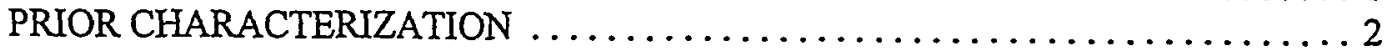

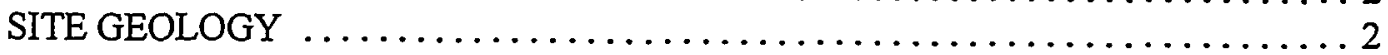

HYDROLOGIC INVESTIGATION METHODS $\ldots \ldots \ldots \ldots \ldots \ldots \ldots \ldots \ldots \ldots \ldots \ldots$

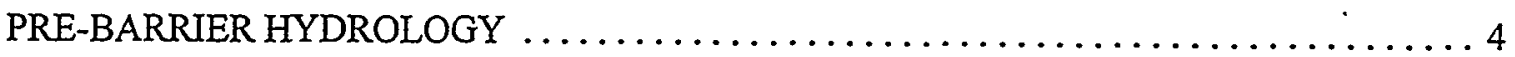

WATER TABLE CONFIGURATION AND STORM RESPONSE $\ldots \ldots \ldots \ldots \ldots \ldots 4$

TRACER DISTRIBUTION $\ldots \ldots \ldots \ldots \ldots \ldots \ldots \ldots \ldots \ldots \ldots \ldots \ldots \ldots \ldots \ldots \ldots \ldots$

PRE-BARRIER CONTAMINANT TRANSPORT PATHWAYS $\ldots \ldots \ldots \ldots \ldots \ldots 6$

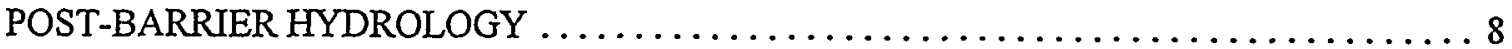

WATER TABLE SUPPRESSION $\ldots \ldots \ldots \ldots \ldots \ldots \ldots \ldots \ldots \ldots \ldots \ldots, \ldots \ldots \ldots$

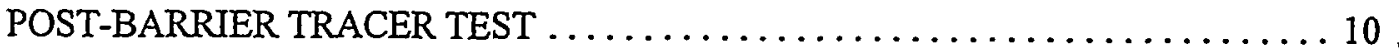

CONCLUSIONS: CRYOGENIC BARRIER PERFORMANCE $\ldots \ldots \ldots \ldots \ldots \ldots \ldots 11$

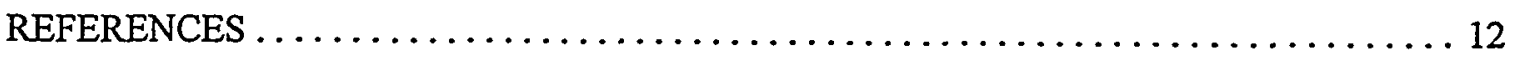

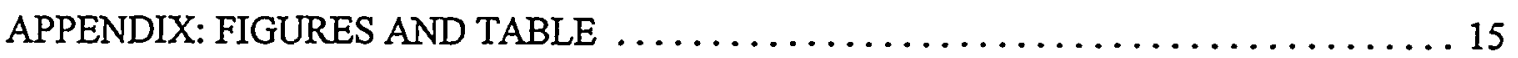




\section{EXECUTIVE SUMMARY}

The Homogeneous Reactor Experiment (HRE) Pond is the site of a former settling pond that received radioactive wastes from 1957 to 1962 , and was subsequently drained, filled with soil, and covered with an asphalt cap. The site is bordered to the east and south by an unnamed stream that contains significant concentrations of radioactive contaminants, primarily ${ }^{90} \mathrm{Sr}$. Because of the proximity of the stream to the HRE disposal site and the probable flow of groundwater from the site to the stream, it was hypothesized that the HRE Pond has been a source of contamination to the creek.

The HRE-Pond was chosen as the site of a cryogenic barrier demonstration to evaluate this technology as a means for rapid, temporary isolation of contaminants in the type of subsurface environment that exists on the ORR. The purpose of this investigation was to evaluate the hydrologic conditions within and around the pond prior to, during, and after the cryogenic barrier emplacement. The objectives were (1) to provide a hydrologic baseline for post-barrier performance assessment; (2) to confirm that the pond is hydraulically connected to the surrounding sediments, (3) to determine the likely contaminant exit pathways from the pond, and (4) to measure changes in hydrologic conditions after barrier emplacement in order to assess the barrier performance. Because relatively little information about the subsurface hydrology and the actual configuration of the pond existed, data from multiple sources was used to reconstruct and characterize this complex system.

The pre-barrier evaluation consisted of water level monitoring in and around the pond and dye and helium tracer tests conducted under forced gradient and ambient flow conditions, respectively. These data conclusively demonstrated that the pond was not hydrologically isolated from the surrounding sediments and could, therefore, provide a source of radionuclide contamination to the White Oak Creek system. Sediments were logged and radiation levels monitored during drilling of 58 boreholes into the boundaries of the original pond, and these data were used to construct geologic cross sections and to determine probable contaminant exit pathways. Thermoprobes were installed in 50 of the boreholes, and freezing was initiated on September 8, 1997.

Following initiation of freezing, the water table within and downgradient of the pond dropped, and all hydrologic response to storms within the pond ceased, indicating that the cryogenic barrier was effectively blocking recharge into the pond. However, 15 days after the injection of a second dye tracer inside of the barrier, the tracer was detected in a standpipe outside of the barrier northwest of the pond and, subsequently, in several other wells to the north and west of the pond. This was in spite of temperature measurements indicating that the subsurface was successfully frozen from the ground surface to more than 9 meters depth, and in opposition to the average hydraulic gradient in that location.

Careful examination of all of the data together led to a conclusion that one or more of the original inlet pipes may have been left in place prior to burial of the pond, creating an air-filled tube that could not be frozen and could subsequently provide an exit pathway for the dye tracer in the northwest location. This explanation is supported by an electromagnetic survey completed in 1996 that suggested the presence of a pipe entering the pond through the northern boundary. A series of water injections following the dye injection most likely created a gradient reversal, driving the flow of dye-laden water out of the pond through the pipe, a reasonable scenario based on the water level data.

The pre- and post-barrier data demonstrate that, but for one breach that is probably due to the presence of a buried pipe, the cryogenic barrier technology was effective for rapid isolation of the pond. The demonstration points to the need for adequate knowledge of any engineering structures that may interfere with formation of the barrier. 


\section{INTRODUCTION}

The Homogeneous Reactor Experiment (HRE) Pond is the site of a former impoundment for radioactive wastes on the Oak Ridge Reservation (ORR) in east Tennessee. The pond received radioactive wastes from 1957 to 1962, and was subsequently drained, filled with soil, and covered with an asphalt cap. The site is bordered to the east and south by an unnamed stream that contains significant concentrations of radioactive contaminants, primarily ${ }^{90} \mathrm{Sr}$. Because of the proximity of the stream to the HRE disposal site and the probable flow of groundwater from the site to the stream, it was hypothesized that the HRE Pond has been a source of contamination to the creek.

The HRE-Pond was chosen as the site of a cryogenic barrier demonstration to evaluate this technology as a means for rapid, temporary isolation of contaminants in the type of subsurface environment that exists on the ORR. The cryogenic barrier is created by the circulation of liquid $\mathrm{CO}_{2}$ through a system of thermoprobes installed in boreholes which are backfilled with sand. The probes cool the subsurface, creating a vertical ice wall by freezing adjacent groundwater, effectively surrounding the pond on four sides.

The purpose of this investigation was to evaluate the hydrologic conditions within and around the pond prior to, during, and after the cryogenic barrier emplacement. The objectives were (1) to provide a hydrologic baseline for post-barrier performance assessment; (2) to confirm that the pond is hydraulically connected to the surrounding sediments, (3) to determine the likely contaminant exit pathways from the pond, and (4) to measure changes in hydrologic conditions after barrier emplacement in order to assess the barrier performance. Because relatively little information about the subsurface hydrology and the actual configuration of the pond existed, data from multiple sources was required to reconstruct this complex system.

\section{BACKGROUND}

The HRE Pond is located in Melton Valley immediately adjacent to several buildings that comprise the former experimental reactor complex (Fig. 1; See the Appendix for the figures and table). The pond was constructed in 1955 by excavating into the previous slope to create the northern and western sides of the pond, and by using earth fill to create a clay berm along the eastern and southern sides of the pond [Stansfield and Francis, 1986]. The lower portion of the pond was apparently unlined and the bottom of the pond was no more than a foot above bedrock, based on the results of soil cores obtained by augering through the pond [Stansfield and Francis, 1986].

While in operation from 1957 to 1962, the pond was used as a settling basin for low-level radioactive waste in the form of condensate from an evaporator in the process liquid waste system and shield water exposed to the reactor circuits. Contaminant settling was accelerated by the application of flocculants including ferric flocculants, trisodium phosphate, and diatomaceous earth. In 1970, the pond was closed by back-filling with clean soils. According to observers, the pond was approximately half full of water and sediments at the time, and had accumulated one to two feet of sediment at the bottom [Stansfield and Francis, 1986]. Following backfilling, the area was covered with a one- to two-foot layer of crushed limestone and capped with asphalt. A system of perforated steel drive-points and standard screened wells were subsequently installed for use in groundwater monitoring. 


\section{PRIOR CHARACTERIZATION}

In 1986, the soil and groundwater in and around the HRE pond was characterized in order to estimate the inventory of waste contained in the pond [Stansfield and Francis, 1986]. Six soil borings were obtained from within the pond and based on the soil tests it was determined that ${ }^{90} \mathrm{Sr}$ and ${ }^{137} \mathrm{Cs}$ were the primary radiological constituents, with inventories estimated at $75 \mathrm{Ci}$ and $16 \mathrm{Ci}$, respectively. Detailed results of the soil analyses, found in the appendix of Stansfield and Francis [1986], are summarized here. Cores were obtained by advancing a split-spoon sampler ahead of the auger bit to a depth of refusal, which was described as highly fractured calcareous shale. In all cases, this depth exceeded the elevation of the base of the pond ( $\left.244.7 \mathrm{~m} ; 803^{\prime}\right)$. Boreholes were subsequently backfilled with sand and plugged with concrete at the surface. Similar soil patterns were encountered in each borehole: approximately four inches of asphalt, one foot of crushed limestone, brown clay fill mixed with shale and limestone fragments down to approximately five feet, followed by brown clayey soils with grey-colored zones and inclusions down to an elevation of $244.7 \mathrm{~m}$, consistent with the bottom of the pond. The change in color from brown to mixed and the depth at which water was encountered in the soil cores coincided with the elevation of the top of the original pond $(247.8 \mathrm{~m} ; 813 \mathrm{ft})$. The soil core located at the NW corner of the pond had the highest radiological levels, with a localized portion of the core reading approximately $100 \mathrm{mR}$ at a depth consistent with the top of the pond.

In 1996 an electromagnetic conductivity survey of the HRE-Pond area was conducted to identify areas potentially containing buried drums, metallic pipes, and other metallic debris [Kaufmann, 1996]. The survey identified areas of high- and low-conductivity anomalies (Fig. 2). One striking anomaly is the low-conductivity linear feature at the north end of the grid, extending through the north wall of the former pond and interpreted as a subsurface pipe. Two other anomalies were interpreted as possible buried scrap metal in the NW and SE corners of the pond.

\section{SITE GEOLOGY}

Bedrock underlying the HRE-Pond area consists of two geologic units of the Conasauga Group: the Rogersville Shale and the underlying Friendship Formation. Hatcher et al. [1992] describe these formations as follows. The Rogersville Shale is characterized by interbedded maroon to chocolate-brown mudstones and grey to grey-green calcareous and noncalcareous siltstones. By contrast, the Friendship Formation consists of light-grey, micritic to coarsely crystalline thinly- to moderately-bedded limestone with dark grey or maroon shale interbeds. The contact between these geologic units is abrupt and marked by the absence of limestone beds

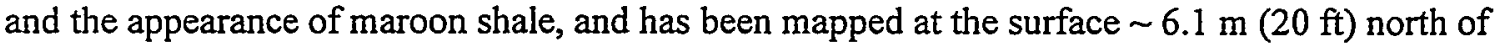
the asphalt cap. Locally, bedding dips from 30-40 degrees to the SE, making it likely that the deeper boreholes intersect the geologic contact at depth, particularly on the north end of the pond.

The bedrock has been complexly deformed, and fractures and fracture intersections are likely to dominate groundwater flow and contaminant transport directions. Highly weathered shale saprolite forms a clay-rich cover over the undisturbed bedrock surrounding the pond. Because the saprolite retains the overall structure of the bedrock, fracture-dominated flow has also been observed in the shallow groundwater system within the saprolite elsewhere on the ORR [Moline et al., 1998; Solomon et al., 1992]. Weathering processes increase the porosity and clay content of the matrix material, resulting in low-permeability high porosity residuum that provides the means for significant storage of contaminants through matrix diffusion and sorption processes. Thus both reactive and nonreactive solutes are retained in the stagnant porewaters of the bedrock and saprolite where they can provide a secondary source over time [Moline et al., 1998; Sanford 
et al., 1996]. As a result, contaminant levels may not be a good measure of performance for any type of containment in these materials in the near term, and other measures must be relied on.

\section{HYDROLOGIC INVESTIGATION METHODS}

In order to establish a baseline for groundwater flow and transport and to confirm that the pond was hydraulically connected to the surrounding soils and, therefore, a probable source of contaminants to the stream, water level monitoring and pre-barrier tracer tests were conducted under forced-gradient and ambient flow conditions. Due to budgetary constraints, the pre-barrier hydrologic investigations relied upon preexisting site instrumentation (Fig. 3). Initial access to the interior of the pond beneath the asphalt cap was limited to a single standpipe penetrating the cap at the center of the pond (12, Fig. 3). A shallow well was later installed at the southeast corner of the pond and provided an additional monitoring point for post-barrier assessment. Shallow groundwater monitoring at the water table interval utilized a network of standpipes (labeled S1 through S10 in Fig. 3) penetrating the asphalt cap immediately outside of the pond itself. All standpipes are four-inch diameter steel pipes with one-inch diameter holes drilled along the subsurface length at one-foot spacings. While not optimal, the standpipes afforded sufficient connection with the surrounding groundwater to allow rapid response during storm events, as evidenced by the continuous water level data. Groundwater below the water table interval was monitored using a network of screened monitoring wells, also shown on Fig. 3. Initial water level monitoring was done manually. Later, many of the wells and standpipes were instrumented with continuous water level and temperature monitoring devices to provide a more detailed picture of the transient nature of the subsurface hydrology and changes over time with the barrier emplacement. Well and standpipe construction information is summarized in Table 1.

On June 5, 1996, the Environmental Protection Agency (EPA) initiated a dye tracer test to provide confirmation that contaminants were leaking out of the pond and to identify contaminant transport pathways and patterns [Field, 1996]. A slug of eosine dye concentrate was injected into the central standpipe (I2) followed by 5 days of water injection to force the dye tracer out of the standpipe and to accelerate transport. On the following day, a continuous injection gas tracer test was also initiated. The central standpipe was instrumented with a passive gas injection system [Sanford et al., 1996] consisting of a central riser constructed of 1-in. PVC pipe and screen around which $400 \mathrm{ft}$ of $1 / 8$-in Teflon tubing was wrapped. Helium was continuously injected from a gas cylinder through the tubing and back to the surface, where it discharged to the atmosphere Similar injection systems have been used successfully for gas tracer tests at other locations [Moline and Schreiber, 1996; Sanford et al., 1996; Knowles et al., 1995; Jardine et al., 1995; Huff and Sanford, 1995].

Fluorescent dye and gas tracer samples were obtained from multiple locations using a variety of methods. Passive diffusive samplers [Sanford et al., 1996] were installed in all of the wells and standpipes to measure the helium tracer. This method allows the gas tracer to be extracted and brought to the laboratory for analysis without disturbing the flow system and without extracting contaminated water that then must be disposed of. Analysis was done by direct injection into a gas chromatograph equipped with a thermal conductivity detector. Following the onset of injection, samples were obtained twice a week for the first six weeks of the test, and less frequently thereafter through September, 1996. Helium injection continued throughout this period. The dye tracer was measured by grab samples obtained from wells, standpipes, and surface water locations. In addition, a number of wells were instrumented with charcoal "bugs" onto which the dye tracer would sorb, thereby providing a cumulative measure of the presence of dye tracer at those locations [Field, 1996]. 
In order to assess transport under ambient conditions during the winter wet season, a second helium injection was initiated on March 12, 1997 and continued through June 25, 1997. A modified sampler was developed in which the sealed end of the copper tube was replaced with a Mininert syringe valve through which the gas samples were extracted in the field using a gastight syringe. All connections were sealed with epoxy.

On May 8, 1997, drilling began for first phase of the cryogenic barrier installation. Fifty-

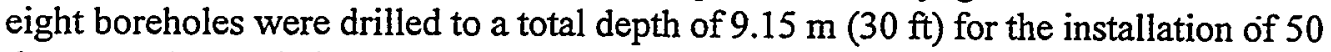

thermoprobes and eight strings of temperature probes, and an additional borehole was drilled to a total depth of $2.74 \mathrm{~m}(9 \mathrm{ft})$ feet for the installation of a piezometer. In most cases, the holes were augered down to refusal and then drilled to the final depth using air-rotary methods. During augering, subsurface materials were characterized and monitored for radiation levels. Characterization was not possible during air-rotary drilling, however, because a closed system where cuttings and drill water were piped directly into a container was used to prevent the spread of contamination. The borehole logs were used to construct geologic cross sections along each wall of the pond to aid in interpreting the subsurface hydrology and to map probable contaminant transport pathways.

Following emplacement of the cryogenic barrier, a second dye tracer injection was conducted using the center standpipe and subsequent water injections as before. Phloxine $\mathrm{B}$ dye was used in place of eosine to eliminate potential problems with interpretation due to residual dye in the system from the first injection. Water level monitoring continued for 11 months following the initiation of barrier freezing.

\section{PRE-BARRIER HYDROLOGY}

The following section describes the results of piezometric monitoring, tracer tests, and geologic logging, and summarizes the subsurface hydrologic conditions prior to the emplacement of the cryogenic barrier.

\section{WATER TABLE CONFIGURATION AND STORM RESPONSE}

Figure 4 shows a water table map and measured hydraulic heads obtained on July 8, 1996. In an isotropic porous medium, groundwater flow is expected to be perpendicular to the hydraulic head contours. This may be a reasonable gross representation for flow through the fill materials within and overlying the pond, where any structure that might have been present in the original material would have been destroyed. However, flow through the undisturbed shale bedrock and overlying saprolite surrounding the pond is expected to be heavily influenced by the fracture network, based on observed anisotropy and strike-preferential flow in similar materials on the ORR.

Composite hydrographs for the standpipes and wells derived from manual water level measurements are shown in Fig. 5. These data indicate downward gradients along all margins of the cap, and upward gradients east of the pond close to the stream. Well 0673 is flowing during much of the winter wet season. These downward gradients surrounding the pond suggest that any contaminants leaking from the pond would be carried downward through the shallow groundwater system to some extent before being discharged to the adjacent stream. On average, water levels were only slightly higher in the winter months of 1996-97, and the pattern of 
hydraulic heads did not change significantly. However, direct comparison of continuous and manual water level measurements is difficult at best, and the continuous water level measurements for the summer of 1997 represent conditions that were disturbed by drilling and installation of the cryogenic barrier probes.

Although seasonal variations in the water table were small, storm-driven variations were quite large in many wells. Fig. 6 shows hydrographs for each of the wells equipped with continuous water level monitoring devices. All but two logging devices also recorded temperature variations. Some of the monitoring devices were moved from their original locations to obtain data at other locations, resulting in short records for those locations. Comparison of these hydrographs with those obtained from manual measurements demonstrates that much of the storm response is not captured without continuous monitoring. In many cases, the peak storm response occured over a period of a few hours and were as much as a meter or more (e.g., Figs. 6d, 6k).

Several conclusions can be drawn from the well hydrographs. First, the rise in water table in some locations is large enough to intersect the gravel layer and was therefore likely to be driving episodic contaminant release from the pond through this high-permeability layer. This release could have occurred either through the transport of fine sediment to which radionuclides are sorbed, or through the flushing of water remaining in the sediments between storm events and providing a means for leaching radionuclides from the soils. An example of the rapid storm response can be seen in the hydrograph for the center standpipe 12 (Fig. 6F). The elevation of the asphalt cap is $249.5 \mathrm{~m}(818.5 \mathrm{ft})$ at this location, and the storm-driven water levels often exceed $249 \mathrm{~m}(817 \mathrm{ft})$ which is a conservative estimate for the bottom of the gravel layer at this location based on an assumption of a one-foot thickness. A more likely estimate is $248.7 \mathrm{~m}$ ( $816 \mathrm{ft}$ ), where the slope of the recession curve changes sharply as discussed in the following section. Second, water temperature fluctuations associated with storm events demonstrate that significant groundwater flux was moving through the system during these events. The response is seen most clearly during winter months due to the more pronounced temperature differences between the ambient groundwater and the infiltrating precipitation. Third, the elevation of the water table exceeded the elevation of the top of the original pond. Therefore, the fill above the original pond was saturated during and between storm events, providing a transport pathway for contaminants from the pond if the fill is transmissive enough to allow significant groundwater flux. The rapid decline in water levels in and around the pond following storm events indicates that the materials saturated during these events are, in fact, significantly transmissive.

The majority of the hydrographs exhibit definite breakpoints in the recession curves (i.e., sharp changes in slope) following storm events. Several of the hydrographs demonstrate the consistency of the storm recession slopes and breakpoint elevation over a series of storm events. Where noted, these breakpoints are indicated on the hydrographs by a dashed line. Breakpoints and recession slopes can provide an indication of the relative hydraulic conductivity of various regions in and around the pond because the rate at which the water added to the system during a storm drains is a function of the local hydraulic conductivity and storativity. For example, Shevenell et al. [1996] used breakpoints in the storm recession curves from a number of wells to determine the transmissivities of multiple pore regions in a karst terrain (e.g., conduits, fractures, and matrix pores). Similarly, the HRE-Pond well hydrographs also reflect drainage from multiple pore regions, although in this case the pore regions are more likely to be associated with changes in subsurface materials rather than changes in pore types within the same material, as is the case with the deeper karst wells. The elevation at which a breakpoint occurs indicates the elevation at which a permeability change occurs for water table wells where changes in water level can be attributed to actual dewatering in an unconfined system. This conclusion is supported by comparing the hydrographs with the geologic logs and the pond construction information. 
Several of the hydrographs indicate extreme hydraulic conductivity variations. Water levels in S-6 (Fig. 6k) and S-10 (Fig. 6d) show a rapid rise and equally rapid recovery from storm events, bottoming out at a consistent elevation. Both of these wells are located within drainage ditches that were constructed around the original pond, based on the construction diagram. These ditches would presumably have been constructed out of low-permeability material to contain any pond overflow and prevent release into the surrounding groundwater. The storm response is very similar to the type of response seen in conduit flow, and the base levels may indicate the elevation of the original ditch at that location. Conversely, water levels in S-8 (Fig. 61) are cropped at the upper end, indicating intersection with a high-permeability zone at the upper elevations.

Storm recession curves in the center standpipe (12) indicate a conductivity change at an elevation of $248.7 \mathrm{~m}(816 \mathrm{ft})$. It is reasonable to infer that the slower rate of recession below that elevation may be due to intersection of the water table mound beneath the asphalt cap with the original clay berm.

\section{TRACER DISTRIBUTION}

Interpretation of the helium tracer test results requires the following to be considered. First, the sampling and analysis methods can lead to false negative results if water leaks into the sampler or gas is lost during or subsequent to sampling. However, there are no mechanisms that can lead to a false positive if the chromatographic peak is properly identified using a standard. Second, the helium tracer data cannot be used to determine transport times because it is impossible to definitively state that the helium detected during the second injection was not residual from the first injection. Nevertheless, the gas tracer data do provide independent confirmation of transport out of the pond and evidence that this transport occurs under ambient conditions and not just under the forced-gradient conditions of the dye tracer tests.

Figure 7 shows the locations where helium was detected one or more times, which are consistent with the eosin dye tracer results under initial forced-gradient conditions [Field, 1996]. The most frequent detects occurred in the standpipes (i.e., water table interval) in a radiallydistributed pattern, consistent with transport through either the gravel layer or the more permeable fill above the berm of the original pond. The lack of detection through the dry months and the episodic nature of both dye and helium tracer detections suggests primary transport through high permeability materials that saturate during elevated water table conditions.

The frequent detection of helium in S-10, and less frequently in S-1, in opposition to the average hydraulic gradient is enigmatic. Helium was also detected in well 1109 , but this can be explained by a local downward gradient. Although transport of helium in the gas phase within the gravel layer and subsequent dissolution into the shallow groundwater is possible, groundwater transport from the pond to these locations is confirmed by the presence of eosin dye in standpipe S-10.

It is clear from the tracer data that there were multiple pathways for contaminants to be transported out of the pond, with rapid episodic transport likely during the winter wet season and during storm events year-round. While these data can not confirm that the radionuclide contamination in the creek is due to sources in the pond, they do confirm that the pond was not hydrologically isolated and that contaminant transport from the pond was highly probable during pre-barrier conditions. 


\section{PRE-BARRIER CONTAMUNANT TRANSPORT PATHWAYS}

Soil contamination patterns observed during drilling of the thermoprobe boreholes can provide insight into the possible mechanisms for contaminant leakage out of the pond. Boreholes were augered down to refusal in most cases followed by air rotary drilling to completion at a depth of $9.75 \mathrm{~m}(32 \mathrm{ft})$. Auger refusal represents the depth at which the subsurface material is substantially less weathered, providing more resistance to the drill bit, and is assumed to be the top of bedrock. However, the transition zone, the interface between highly weathered saprolite and competent bedrock, very likely extends several feet below auger refusal. This zone is an important transport zone on the ORR because it contains a dense network of open fractures and has been shown to be a significant transport pathway in the subsurface [Moline et al., 1998]. The thermoprobes extended from the surface to the total depth of the borehole to ensure that this layer was bridged by the cryogenic barrier. Sediments were monitored for beta and gamma radiation during augering, and were classified based on these readings with Category III being the highest contamination levels. Because augered sediments are carried up the auger flights behind the drill bit (i.e., the drill bit was deeper than the depth represented by the sediments seen at the surface at any given time), the depths to intervals between the surface and bedrock are only approximate.

Geologic cross sections in Fig. 8 contain general descriptions of the materials encountered during drilling, soil contamination data, and the projected elevation of the original berm surrounding the pond. The boreholes were drilled directly into the location of the berm as specified in the original engineering diagrams. In all cases, the elevations are approximate and the depth to bedrock represents auger refusal where drilling to refusal occurred. Several key observations can be made based on these cross sections. The elevation at which dense clay material is encountered is very consistent with the elevation of the berm as specified in the engineering diagram. The material above the berm has the characteristics of loose soil-gravel mix and is, therefore, likely to be much more hydraulically conductive than the underlying material. The gravel layer was encountered at every location, demonstrating the continuity of this high-permeability feature across the entire pond.

Soil contamination patterns indicate two primary locations where the contaminated soils are concentrated and, therefore, two probable exit pathways: a shallow pathway at or near the elevation of the berm, and deeper pathways that are in all likelihood associated with the location of pipelines into or out of the pond. The former could be a result of overflow of the pond and concentration of contaminants in the soils of the surrounding drainage ditches prior to capping, and/or subsurface transport through the more permeable fill material above the pond walls due to the rise in the water table following cap installation. According to Stansfield and Francis (1986), the water table rose several feet higher than when the pond was in operation and higher than was projected in response to cap installation. The deeper contaminant concentrations could have been due to either leakage through the pipes themselves or transport along the soils surrounding the pipes.

Figure 9 shows the areal distribution of Category III soils, location of the probe and piezometer boreholes, and key features of the original pond construction. Additional details can be observed in the cross sections identified in Fig. 9 and shown in Fig. 10. The pond construction information was obtained from a preconstruction drawing, and therefore the locations of the ditches, berms, and drainage pipes may not reflect the final locations exactly. For example, the electrical conductivity data suggest a buried pipe penetrating the north wall of the pond that does not exist on the construction diagram. This conductivity anomaly is coincident with the location of very high soil contamination levels that extend well below the elevation of the berm, lending validity to this location as a region where the pond was 
penetrated. The geologic logs are largely consistent with the configuration of the berms as detailed in the construction diagram.

Based on the water level data, tracer distributions, subsurface geology, and soil contamination patterns, the following conclusions regarding the pre-barrier hydrology can be made:

1. The pond was hydrologically active and connected to surrounding soils. This conclusion is supported by the rapid water level and temperature response to storms, both in and around the pond, by the presence of contaminated soils immediately outside of the pond, and by the transport of helium and dye tracers out of the pond.

2. Contaminant release from the pond was probably episodic and correlated to storms. A rapid and substantial rise in water levels in and around the pond during storm events is evident in all of the well hydrographs. Water level elevations exceeded the elevation of the original berm during these events and, in some cases, even intersected the elevation of the gravel layer. High permeabilities in the material overlying the pond are evident by the steep slope of the storm recession curves.

3. Multiple contaminant exit pathways existed that are largely controlled by the nature of the geology within which the pond was constructed, the construction design of the pond, and the subsequent burial and cap installation. These potential pathways include (1) transport from the base of the pond through the highly fractured shallow bedrock, possibly enhanced by the sandfilled boreholes that provide vertical pathways through the pond sediments, and through the fill around the effluent pipeline; (2) transport through the more permeable fill materials overlying the original pond; (3) transport through the gravel layer immediately below the asphalt cap; and (4) transport through the walls of the original pond, possibly related to influent/effluent pipelines and fractures in the walls of the pond.

4. Differences in transport of the dye and gas tracers was due to flooding the pond for several days following dye injection. It is clear that the dye tracer was transported in many directions under artificially-induced gradients. However, the helium tracer test demonstrated that transport out of the pond occurred under ambient conditions as well, and that release from the pond was greatest during the winter wet months, probably as a result of higher overall water levels and more frequent high-intensity storms. Further, the helium tracer test confirmed transport to the NW corner, contrary to expectations but consistent with the distribution of highly-contaminated soils.

\section{POST-BARRIER HYDROLOGY}

Water level and groundwater temperature monitoring was continued throughout the formation of the cryogenic barrier and for several months thereafter, through August 1998. In addition, EPA conducted a second dye tracer injection in February, 1998, six months after the initiation of freezing and after the temperature monitoring indicated that the barrier was frozen over the full depth of the thermoprobes. The following discussion details evidence that suggests that, overall, the cryogenic barrier did hydrologically isolate the pond but also that a breach in the barrier existed at the time of the tracer injection. 


\section{WATER TABLE SUPPRESSION}

Subsequent to installation of the cryogenic barrier, the water table in and around the pond gradually shifted to a new equilibrium that is consistent with the presence of a flow barrier. Figure 11 shows a water table map based on measurements taken on March 30, 1998, six months after the initiation of freezing and a month after the second dye tracer injection. Water levels upgradient (i.e., north and west) of the pond have not changed significantly from the pre-barrier levels other than being slightly higher, reflecting the wet-season levels. Water levels within and downgradient (i.e., east and south) of the pond were significantly impacted. The water table within the pond dropped slowly over a period of many months following the initiation of freezing, as shown in the hydrograph for standpipe I2 (Fig. 6f). The slow decline could have been due to one or more mechanisms, including slow seepage through the low-permeability base of the pond, which is not blocked off by the cryogenic barrier, and loss of water to the ice walls themselves.

The hydrograph for 12 contains several perturbations that require some description. During the initial slow decline, the water level data contain increasingly larger levels of noise due to problems with the pressure transducer. Data were continuing to be recorded during a period when the water level monitoring was discontinued due to lack of budget to support the activity, and the lack of maintenance of the monitoring system resulted in moisture buildup in the pressure equilibration tube and large diurnal shifts that are temperature related. Thus, these data have been smoothed and provide an indication of the average only, without any storm response.

Just prior to the onset of the tracer test in February, the pressure transducer was replaced with a Troll monitoring system, which caused displacement of water in the standpipe and the apparent water level rise at that time. The water level resumed a slow decline at that point, but was most likely higher in the standpipe than in the surrounding material due to the low permeability of the materials surrounding the standpipe. Figure 12 shows a schematic cross section of the pond after the cryogenic barrier was in place. Because of the hydraulic conductivity differences between the compacted material in the pond and the higher conductivity fill overlying the pond, any rise in water level in the standpipe due to displacement by the probe or injection during the tracer tests will dissipate quickly down to the level of the compacted material and then much more slowly thereafter. The water level data obtained after the probe was replaced are absent of noise, and the lack of any storm response is immediately apparent. The only peaks seen during this period correspond to water injections during the tracer test, described below, even though there were numerous storm events during this period. Contrast this to the data prior to the onset of freezing where every significant storm resulted in a response in the well. Because the water level in the standpipe on March 30, 1998 does not reflect the true water level in the pond, the water table map in Fig. 11 contains the water level at 12 obtained manually just prior to the exchange of the probe in early February. This value is very close to the water level in a piezometer installed in the southwest corner of the pond (AFIP) during installation of the barrier and providing a second internal monitoring location.

Water levels and groundwater dynamics upgradient of the cryogenic barrier appear unchanged by the presence of the barrier (e.g., Fig. 6d). These data provide a control and demonstrate that changes in groundwater dynamics observed within and around the pond after the barrier was in place are not a result of some regional change due to meteorological or other conditions not related to the presence of the barrier.

Water levels downgradient of the cryogenic barrier are affected by the presence of the barrier, as illustrated in Fig. $6 \mathrm{j}$. Water levels in standpipe S5 dropped roughly two meters following the onset of freezing, and the seasonal low water temperature dropped by 10 degrees Celsius. Both of these effects are consistent with the diversion of flow away from that location, 
resulting in water table suppression and decreased groundwater flux. In addition, the storm response at the new equilibrium water level doubled, and the gradient between S5 and the adjacent deeper well 1110 reversed following barrier emplacement from a downward to an upward gradient. While the temperature data show significant perturbations during storm events before the barrier, very little response occurs after the barrier is in place. A similar change in temperature response to storms is seen in standpipe S6 (Fig. 6k), although the water table does not change at that location. In addition, the overall responsiveness to storms decreases at the location of S6 so that only the largest storms produce the type of response observed before the barrier was in place. S6 would be in the pathway of groundwater diverted around the barrier, and the diminished storm response could simply be a lack of contribution from flow through the pond due to the presence of the barrier.

\section{POST-BARRIER TRACER TEST}

The EPA conducted a second dye tracer injection on February 19, 1998 followed by water injections on February 19, 20, 24, 26, and 27 and on March 4 and 5. Eosine dye was injected into 1109 , outside of the barrier, and phloxine B was injected into the center standpipe, inside of the barrier (Cambrian Ground Water Co., 1999). A total of 260 gallons of water were injected into the two injection wells combined, with roughly half going into each. The hydrograph for the center standpipe (12, Fig. 6f) shows rapid water level increases and equally rapid decrease associated with each of the injections.

The phloxine B dye was detected outside of the pond in standpipes S1 $(5 / 29)$, S2 $(5 / 8,5 / 29)$, S9 (6/24), S10 (3/6, 3/12, 3/23, 4/28, 5/29), and in wells $1112(4 / 29)$ and AFIP $(4 / 28,5 / 8,5 / 29)$. The appearance of the dye tracer in well AFIP is not surprising, since it is located inside the barrier. The long delay between the time of injection and detection simply confirms the low conductivity of the compacted material beneath the fill through which they dye would have to be transported to reach the AFIP screen. What was surprising, however, was that the dye was transported through the barrier to the northwest corner, and that it appeared in S10 before it was detected at any other location.

Appearance of the dye in S10 requires some means for the dye to get through or around the barrier and a hydraulic gradient to drive transport in that direction. Figure 13 shows a composite graph of daily precipitation, water levels in standpipes outside the northwest corner of the pond, and dates and locations of dye tracer detections for the period from the tracer injection on February 19, 1997 through the end of June, 1997. From the water levels alone, it would appear that the dye was transported opposite the direction of the hydraulic gradient between the injection well and standpipes S10 and S1. Only S2 has a lower hydraulic head. However, extreme variations in the hydraulic conductivity of the materials overlying the pond, as evidenced by the hydrograph in Fig. $6 \mathrm{f}$, could have created a perched zone within the gravel layer and a hydraulic gradient toward the northwest corner. Water levels in the injection well were certainly above the baseline level in S10 during the periods of injection. There are no continuous data available for $\mathrm{S} 10$ during the injection period, but since the injections occurred during a relatively dry period it is highly likely, based on S10 data before and after the injection period that the levels in S10 were at the baseline level (Fig. 6d).

Because the temperature data clearly demonstrate that the cryogenic barrier was frozen in the northwest corner (Arctic Foundations, Inc., pers. comm.), the only way that the dye could have escaped from the pond would have been through a breach in the barrier or beneath the barrier. The low hydraulic conductivity of the materials in the pond, evidenced by the slow drainage of the pond following freezing, would likely have resulted in significantly slower transport than 
what occurred. Further, the downward hydraulic gradient in the northwest corner (e.g., between $\mathrm{S} 10$ and 1109) would have prevented transport to S10 via that route. That leaves a breach in the wall as the only other alternative. One way that the wall could have frozen completely but still retained an exit pathway is the presence of a pipe, as suggested by the EM survey. It would have required that the pipe be empty most or all of the time during freezing.

Based on the preconstruction diagram, the inlet pipe would have come into the pond over the berm, which was at an elevation of $247.8 \mathrm{~m}$. By the start of freezing, the water level in the pond had dropped to roughly that elevation (Fig. 6f), so it is likely that if the inlet pipe was not removed prior to burial of the pond it would have been dry at the time of initiation of freezing, with the exception of intermittent flow during storm events. Transport of the dye to S10 would also have required a break in the pipe outside of the barrier, something that could very well have occurred during burial and compaction. Figure 14 shows a diagram of the probable transport pathways based on this scenario. Note that there was no dye detected in any of the downgradient wells that were sampled other than well 1112 . That well is screened well below the base of the pond and would likely have involved a deeper pathway from the point of release outside of the barrier to the well. Also shown on Fig. 14 is the approximate top of the slope of the pond at the time of burial, taken from a pre-capping engineering diagram, showing the expansion of the pond along the entire western perimeter due to slope collapse. Because of this collapse, some of the original drainage features shown in the preconstruction diagram would have been disturbed.

In almost all cases, dye detections were episodic, characteristic of the "flashy" transport observed on the ORR during storm events and reflected in the hydrographs in Fig. 6. Because of these groundwater dynamics and the long intervals between sampling events, some transport events may have been missed and a more definitive picture of the transport pathways cannot be made.

\section{CONCLUSIONS: CRYOGENIC BARRIER PERFORMANCE}

Comparison of the hydrodynamics in and surrounding the pond before and after the cryogenic barrier was formed provides a means for evaluating the effectiveness of the barrier for isolating the pond and preventing further transport of contaminants to the groundwater system. Although the data are insufficient to fully explain all of the phenomena observed, two primary conclusions can be made with respect to the performance of the barrier.

1. The cryogenic barrier significantly reduced or eliminated recharge to the pond. The prebarrier water level and tracer test data clearly demonstrate that the pond was hydrologically active and connected to the surrounding sediments via multiple pathways. Temperature data provided by Arctic Foundations, Inc., show that the barriers did form as predicted and extended from the ground surface to greater than 9 meters depth. Continuous water level monitoring in and around the pond confirm that the flow-through behavior was interrupted by the presence of the barriers. Cessation of a storm response in the center standpipe and water table suppression within and downgradient of the pond confirm that the barrier provides a significant impediment to transport of groundwater into and out of the pond. However, the presence of the dye tracer outside of the barrier following a second tracer injection is indisputable evidence that transport out of the pond occurred even with the barrier in place, even if this was most likely through a buried pipe. 


\section{Dye tracer transport out of the pond was limited compared to pre-barrier conditions and}

appears to be related to existing structures rather than to problems with the cryogenic technology itself. Tracer transport behavior differed greatly from that demonstrated by the prebarrier helium and dye tracer tests in that the transport out of the pond appeared to be restricted to the northwest corner of the pond. Based on the hydrologic data and the EM survey, it is hypothesized that one or more of the inlet pipes that were in place during active use of the pond were simply left in place during burial. This pipe would likely have been empty of water at the time of freezing, based on water level data, and would then have provided an outlet from the pond even with successful freezing of the barrier. The dye tracer would have had the opportunity to be transported through the pipe following injection, when water injections over the following two weeks would very likely have created a perched zone above the compacted material in the pond, allowing for lateral transport to the pipe and creating a temporary gradient reversal between the injection source at $\mathrm{I} 2$ and standpipe S10 where the dye was first detected. A similar dynamic could have occurred during storm events before the barrier was in place, when water was able to move freely along the gravel layer beneath the asphalt cap, thus explaining the presence of the dye and helium tracers in wells along the northwest corner during the pre-barrier tracer testing as well.

Although the only definitive way of confirming this scenario would be to dig a trench along the northern boundary of the pond to look for a pipe or other exit pathway, the explanation suggested in this report is consistent with the data that we do have. In any event it is clear that the barriers did effect a significant change in the pond hydrology, resulting in nearly complete isolation, and demonstrating a rapid means for temporary isolation of waste disposal sites even in very dynamic and complex environments such as the HRE Pond site. For any future application of this technology, however, every effort should be made to determine the presence of structures that could impact the subsurface hydrology and interfere with formation of the cryogenic barrier.

\section{REFERENCES}

Cambrian Ground Water Company, 1998. Final Data Package and Results for Groundwater Tracing Experiments - HRE Cryogenic Barrier Evaluation. September 30, 1998

Field, M. S., 1996. Final Report on the Initial Ground-Water Tracing Results for the FreezeBarrier Demonstration. U.S. EPA SITE Program, October 31, 1996.

Hatcher, R. D., Jr., P. J. Lemiszki, R. B. Dreier, R. H. Ketelle, R. R. Lee, D. A. Leitzke, W. M. McMaster, J. L. Foreman, and S. Y. Lee, 1992. Status Report on the Geology of the Oak Ridge Reservation. ORNL/TM-12074.

Huff, D. D., and W. E. Sanford, 1985. The use of tracers to confirm sources for radioactively contaminated seeps. EOS, Transactions of the American Geophysical Union, v. 76(4) supplement, p.F245.

Jardine, P. M., W. E. Sanford, O. C. Reedy, and J. P. Gwo, 1995. Multicomponent tracer injection at a DOE waste disposal site with fractured porous media: II. Experimental findings. EOS, Transactions of the American Geophysical Union, v. 76(4) supplement, p.F251. 
Kaufman, R., 1996. Electromagnetic conductivity survey of the HRE Pond, memo to Mike Harper, LMES, April 8, 1996.

Knowles, T. L., J. F. McCarthy, and W. E. Sanford, 1995. Multiple nonreactive and reactive tracers to investigate the migration of transuranics in groundwater. EOS, Transactions of the American Geophysical Union, v. 76(4) supplement, p.F238.

Moline, G. R., 1996. Status Report: HRE-Pond Cryogenic Barrier Demonstration Noble Gas Tracer Test. Internal project report, September 19, 1996.

Moline, G. R., and M. E. Schreiber, 1996. FY94 Site Characterization and Multilevel Well Installation at a West Bear Creek Valley Research Site on the Oak Ridge Reservation.

ORNL/TM-13029.

Moline, G. R., M. E. Schreiber, and J .M. Bahr, 1998. Representative groundwater monitoring in fractured porous systems. Journal of Environmental Engineering, v.124(6), p.530-538.

Sanford, W. E., Shropshire, R. G., and D. K. Solomon, 1996. Dissolved gas tracers in groundwater: Simplified injection, sampling, and analysis. Water Resources Research, v. 32 (6), p.1635-1642.

Shevenell, 1996. Analysis of well hydrographs in a karst aquifer: estimates of specific yields and contrinuum transmissivities. Journal of Hydrology, v.174(1996), p.331-355.

Stansfield, R. G., and C. W. Francis, 1986. Characterization of the Homogeneous Reactor Experiment No. 2 (HRE) Impoundment. ORNL/TM-10002. 
APPENDIX

FIGURES AND TABLE 


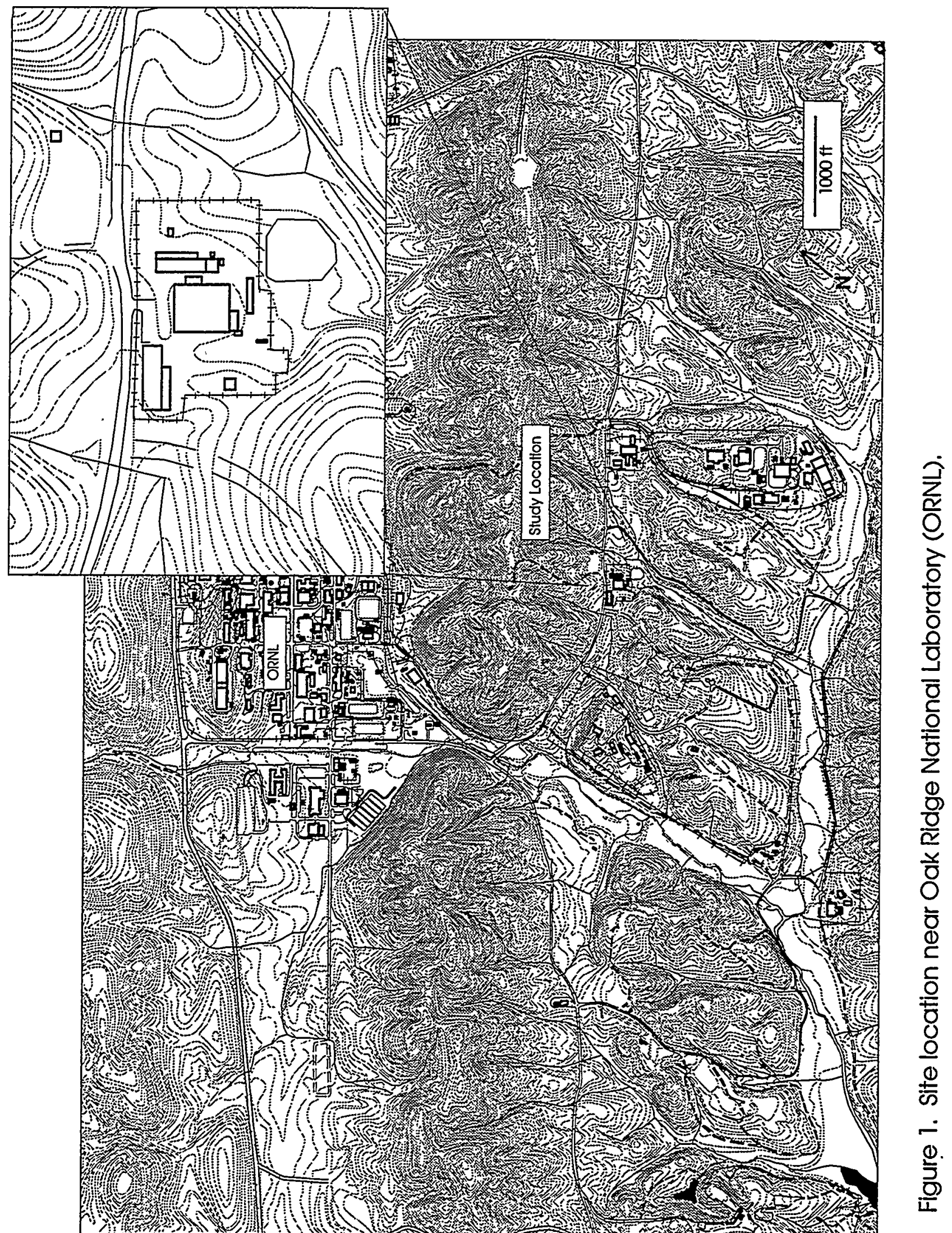




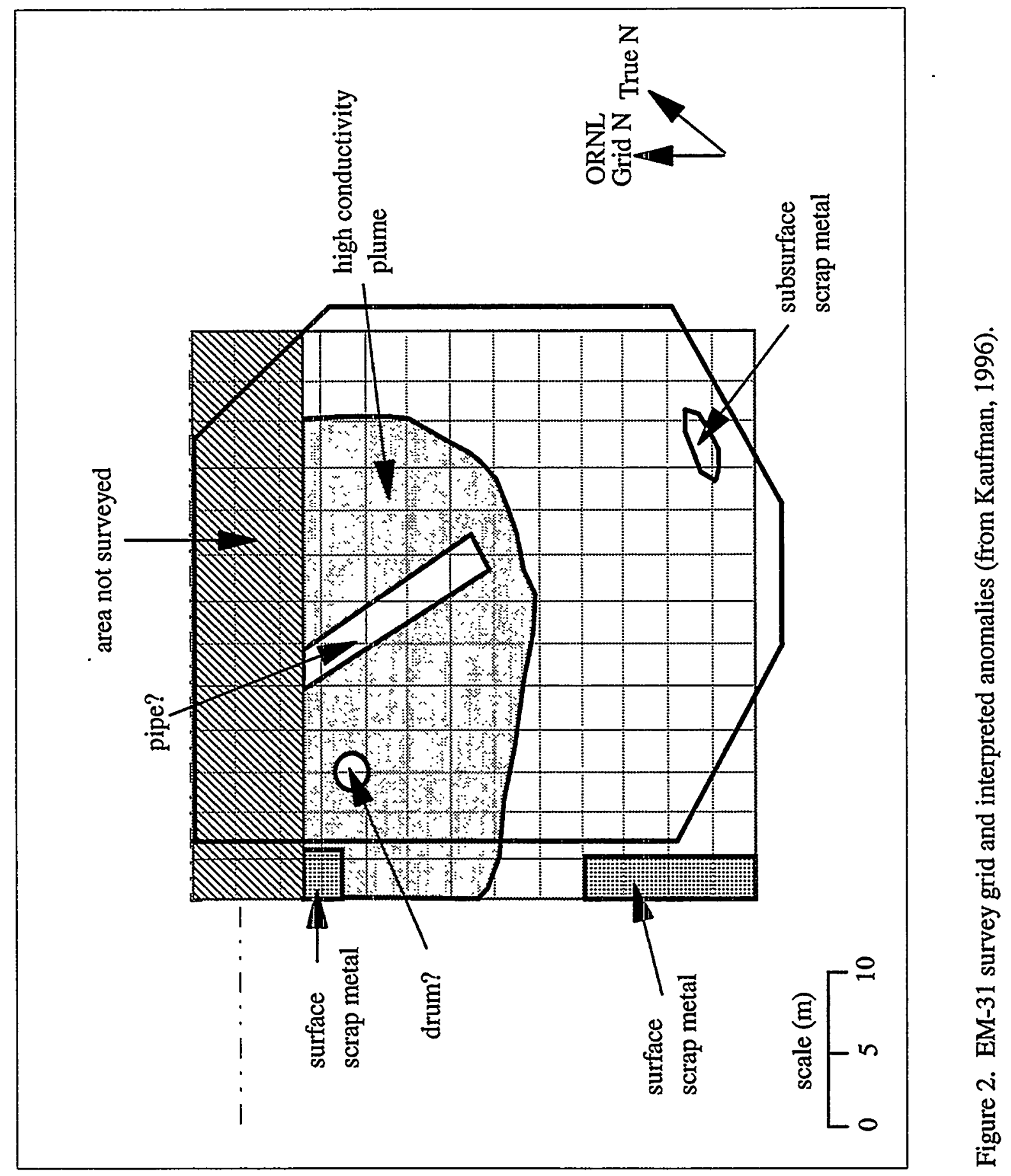




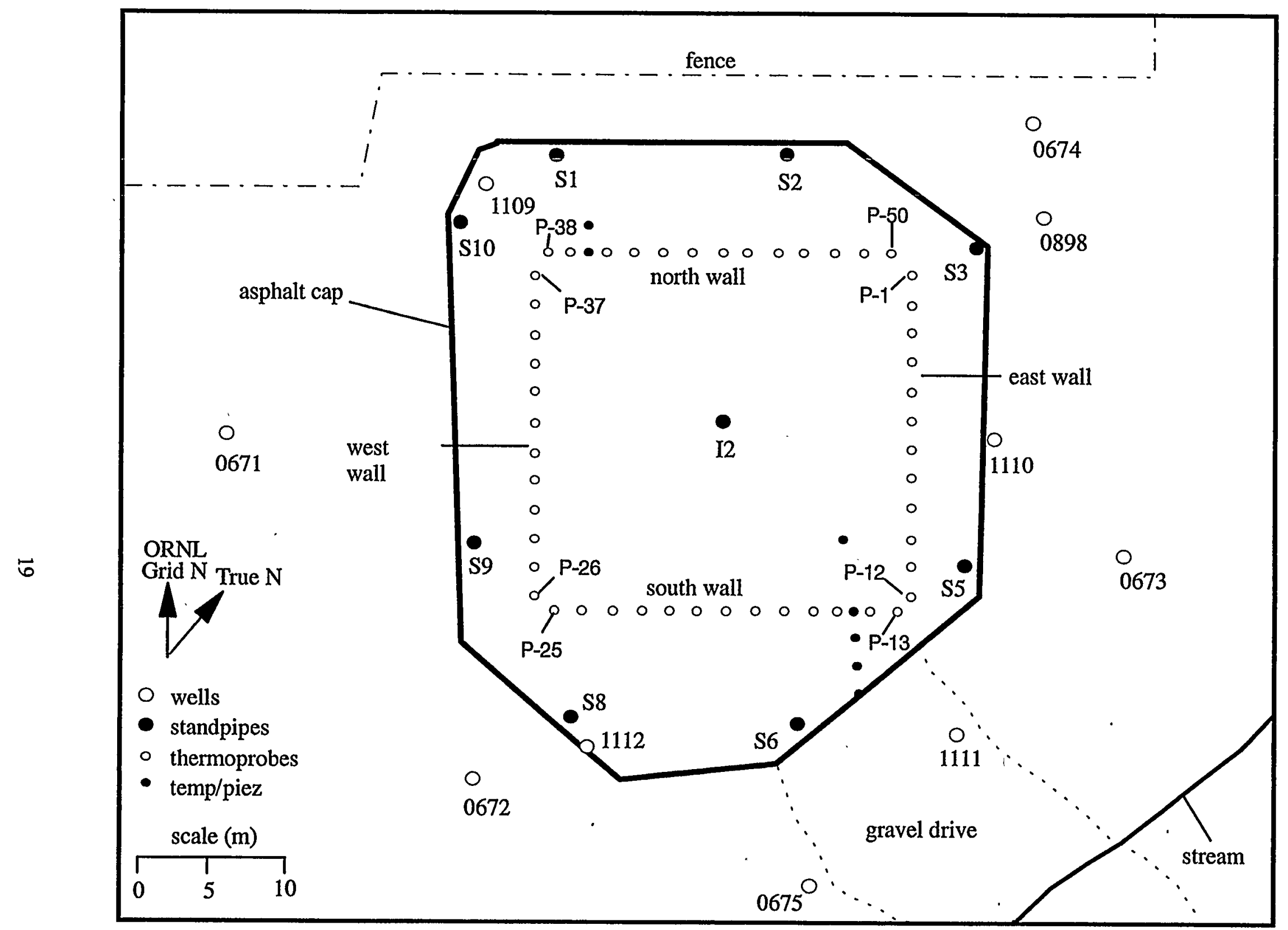

Figure 3. Location of wells, standpipes and thermoprobe boreholes at the HRE-Pond. Thermoprobes are located along the walls of the original impoundment. 


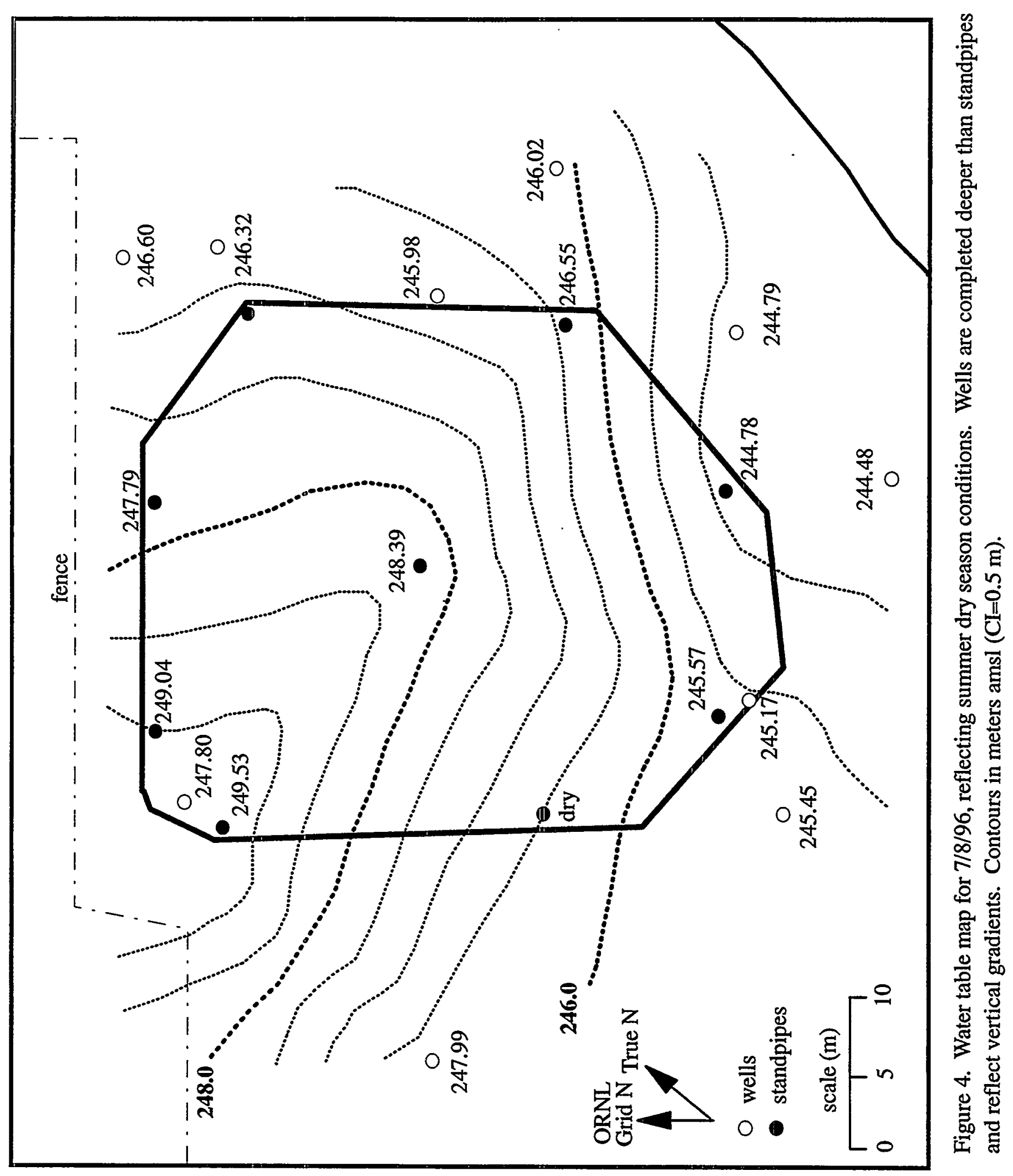



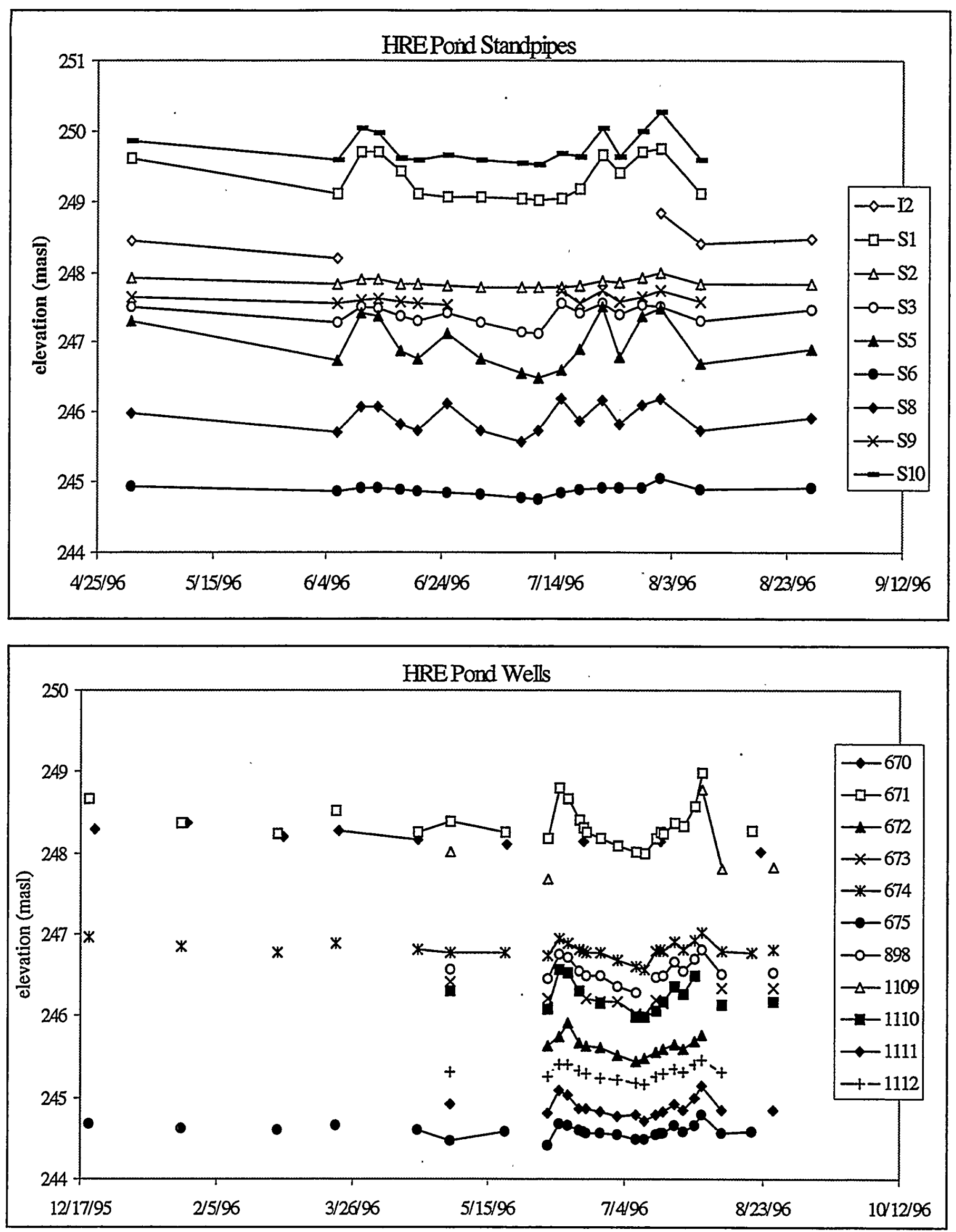

Figure 5. Manual water level data for HRE Pond wells and standpipes. 

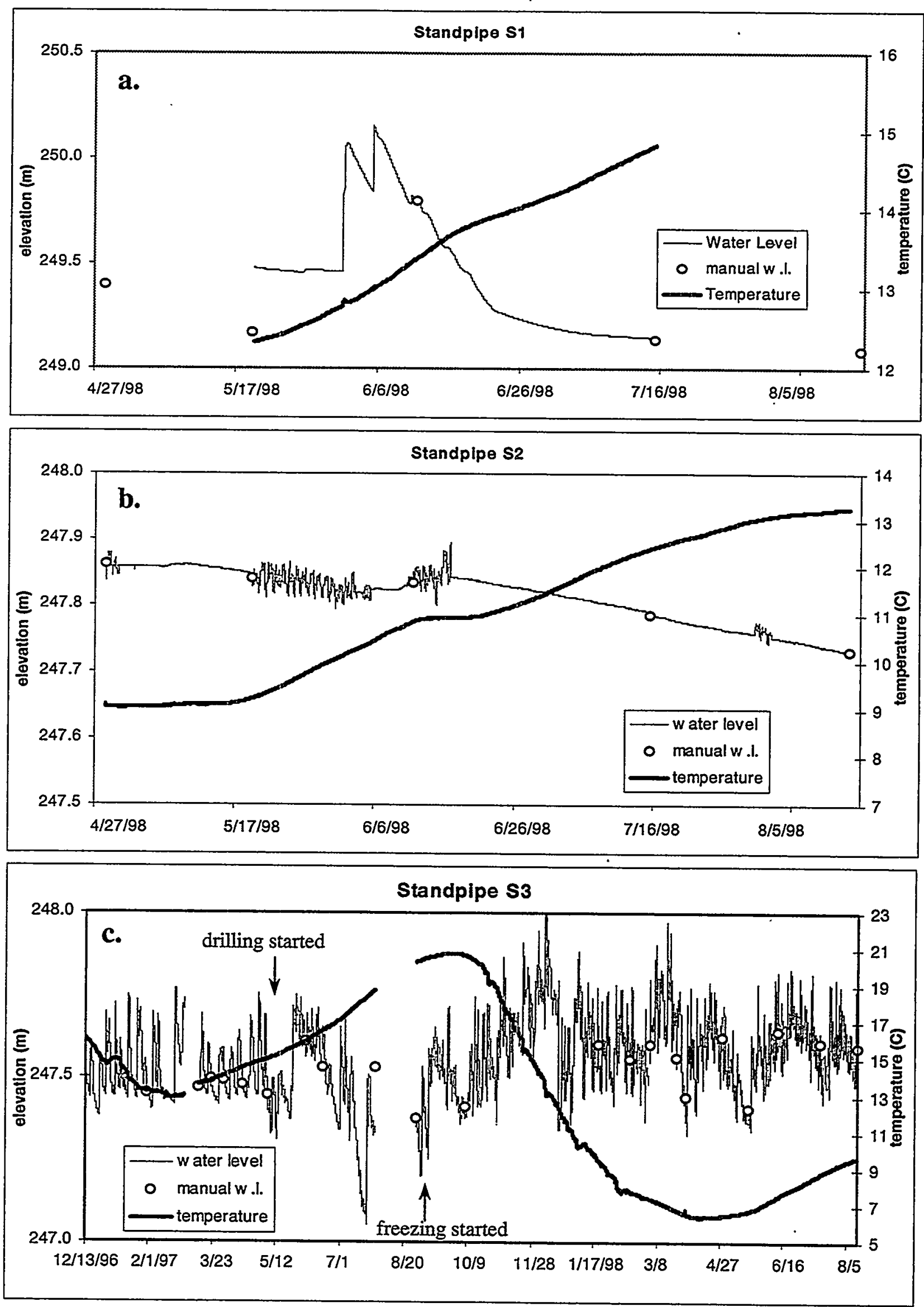

Figure 6. Well hydrographs and groundwater temperature for monitoring locations at the HRE Pond. Dates that drilling and freezing were started are indicated. 

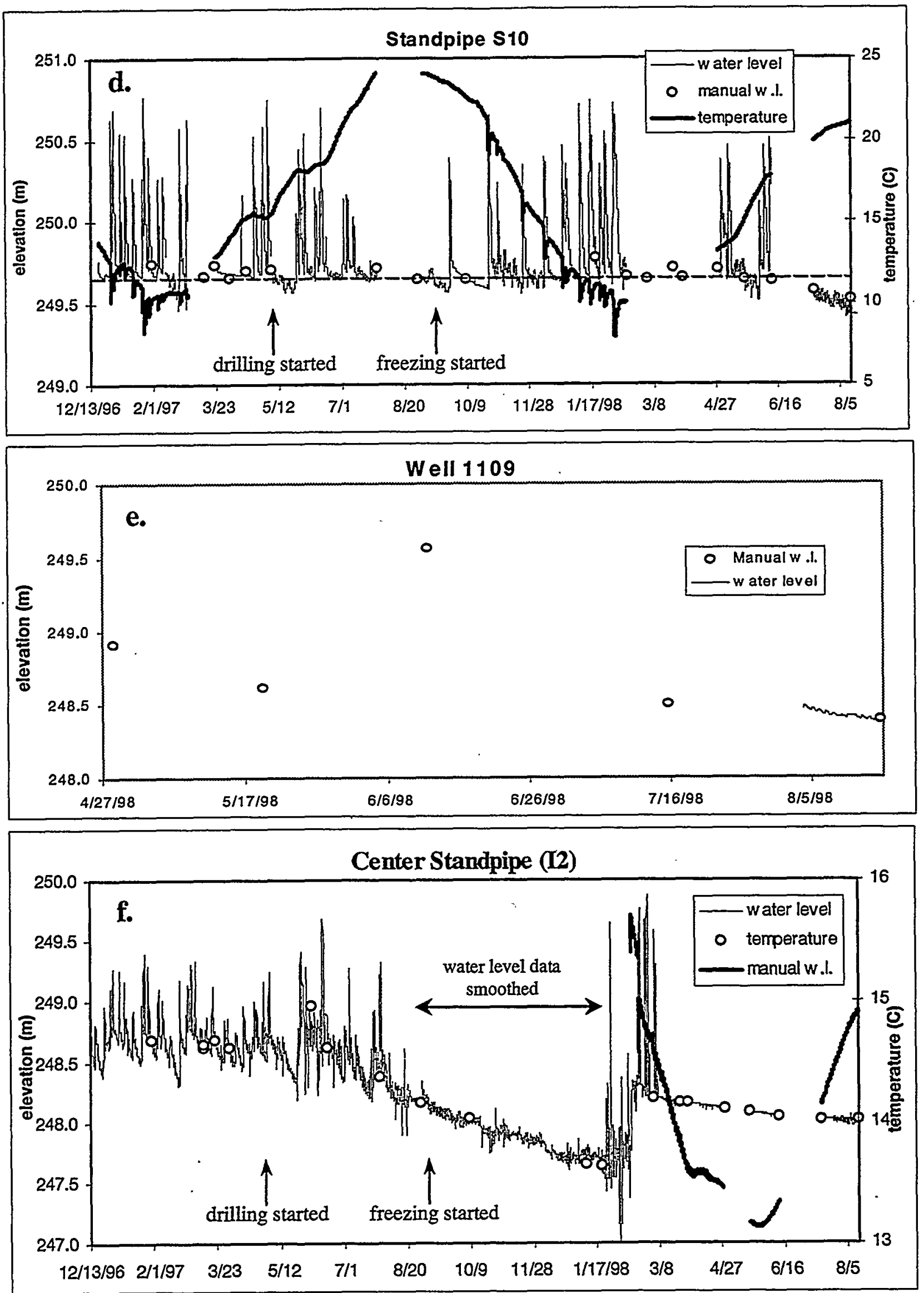

Figure 6 (cont.). Well hydrographs and groundwater temperature for monitoring locations at the HRE Pond. Dates that drilling and freezing were started are indicated. 

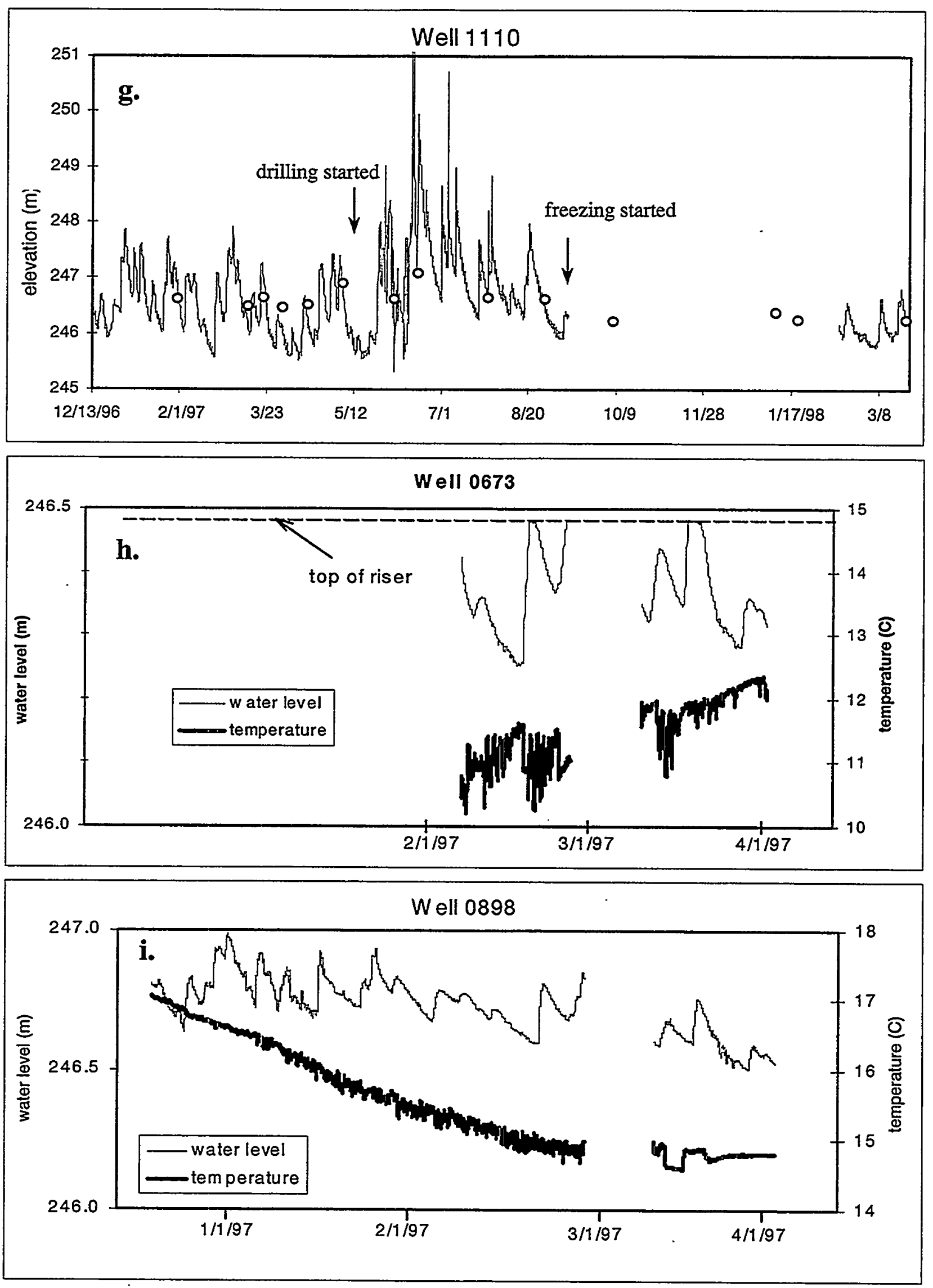

Figure 6 (cont.). Well hydrographs and groundwater temperature for monitoring locations at the HRE Pond. Dates that drilling and freezing were started are indicated. 

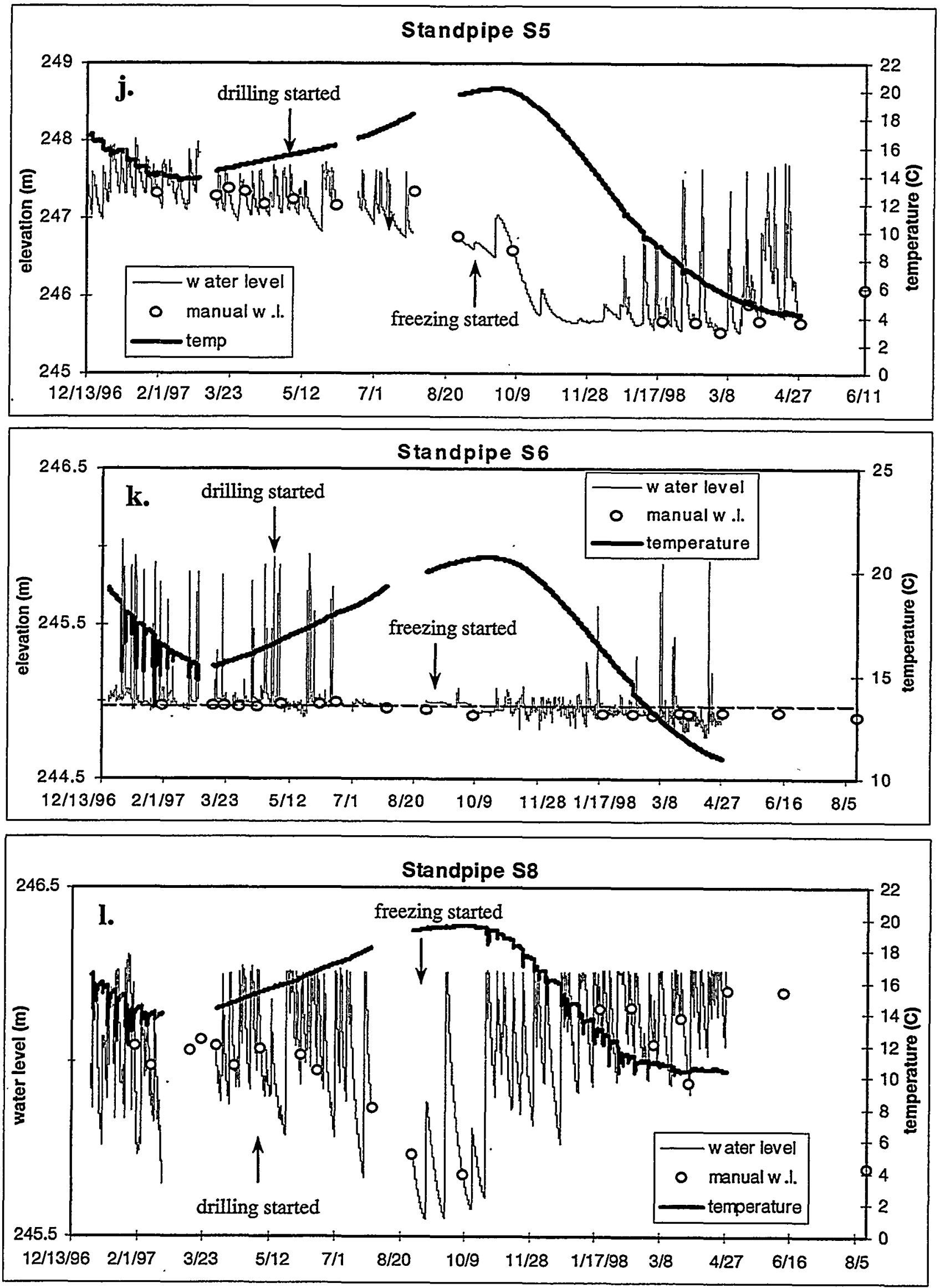

Figure 6 (cont.). Well hydrographs and groundwater temperature for monitoring locations at the HRE Pond. Dates that drilling and freezing were started are indicated. 


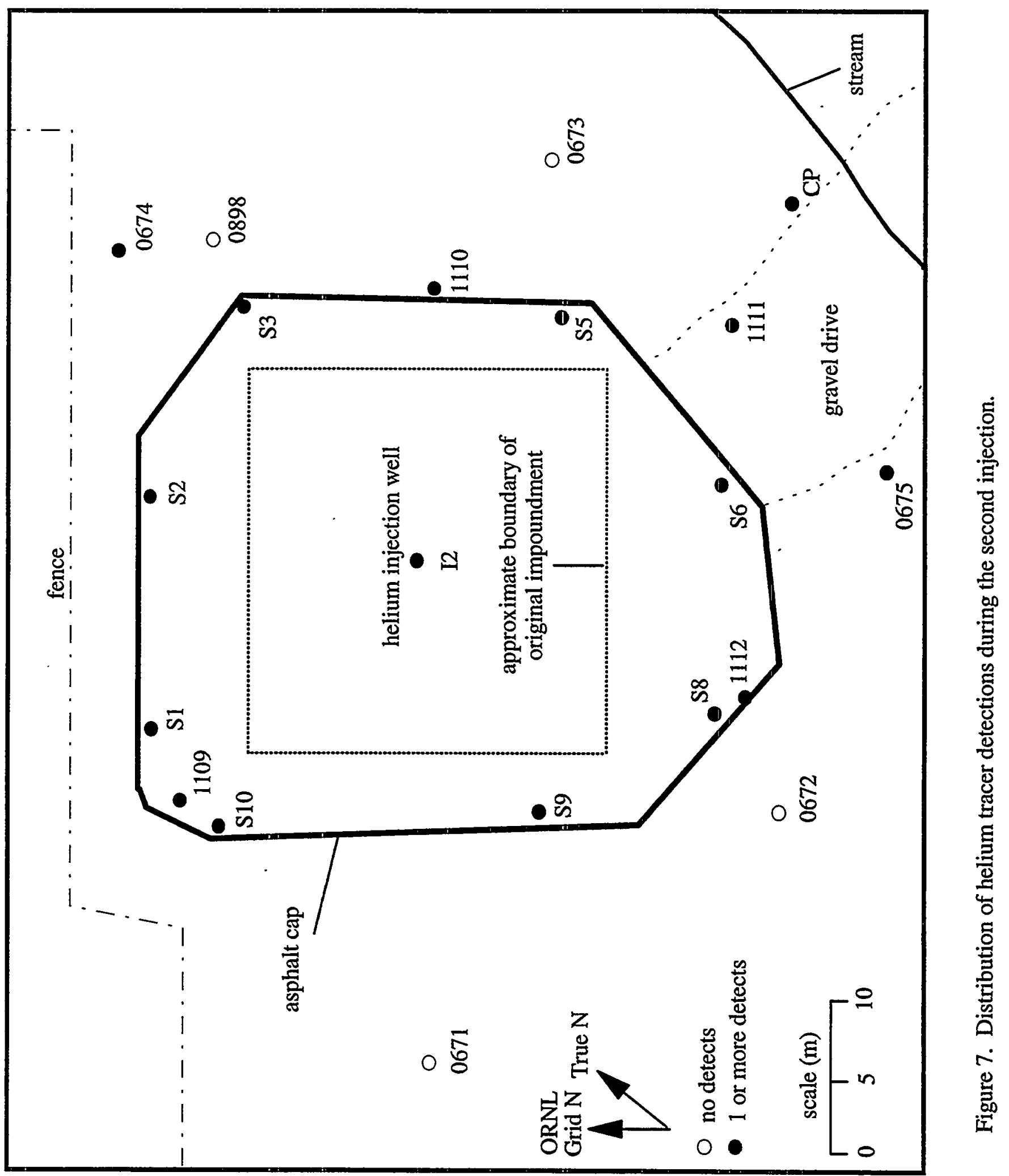




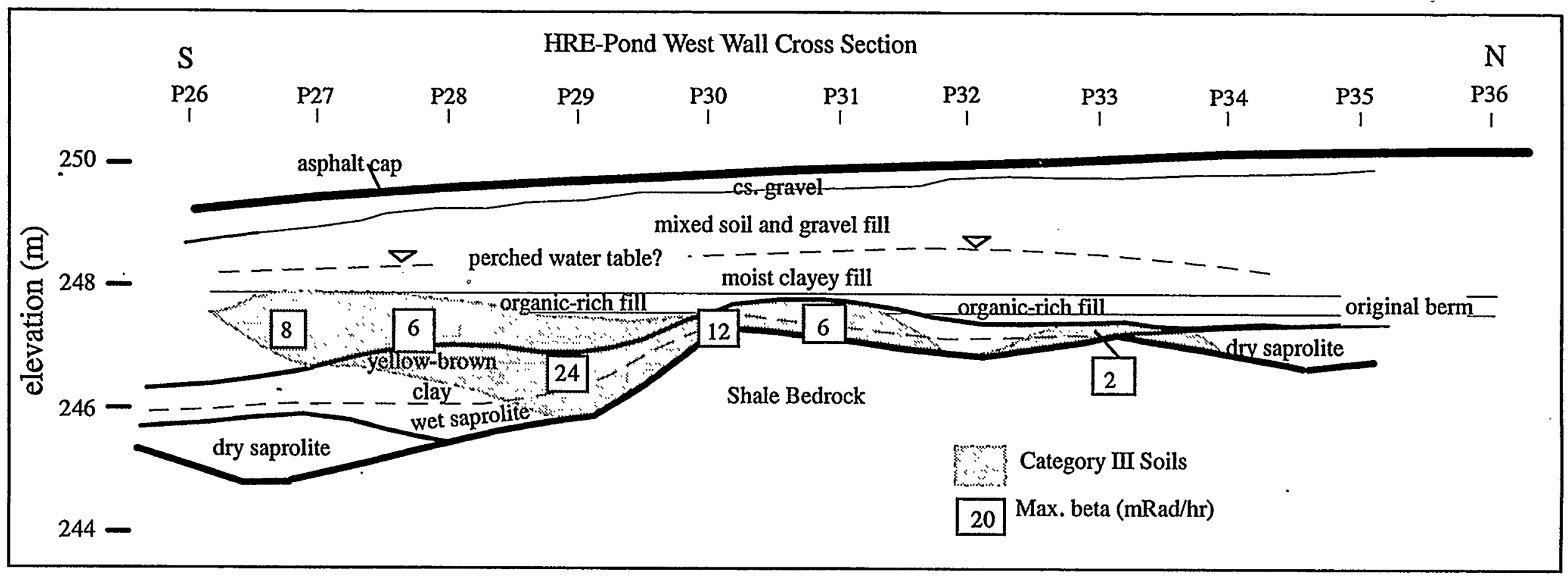

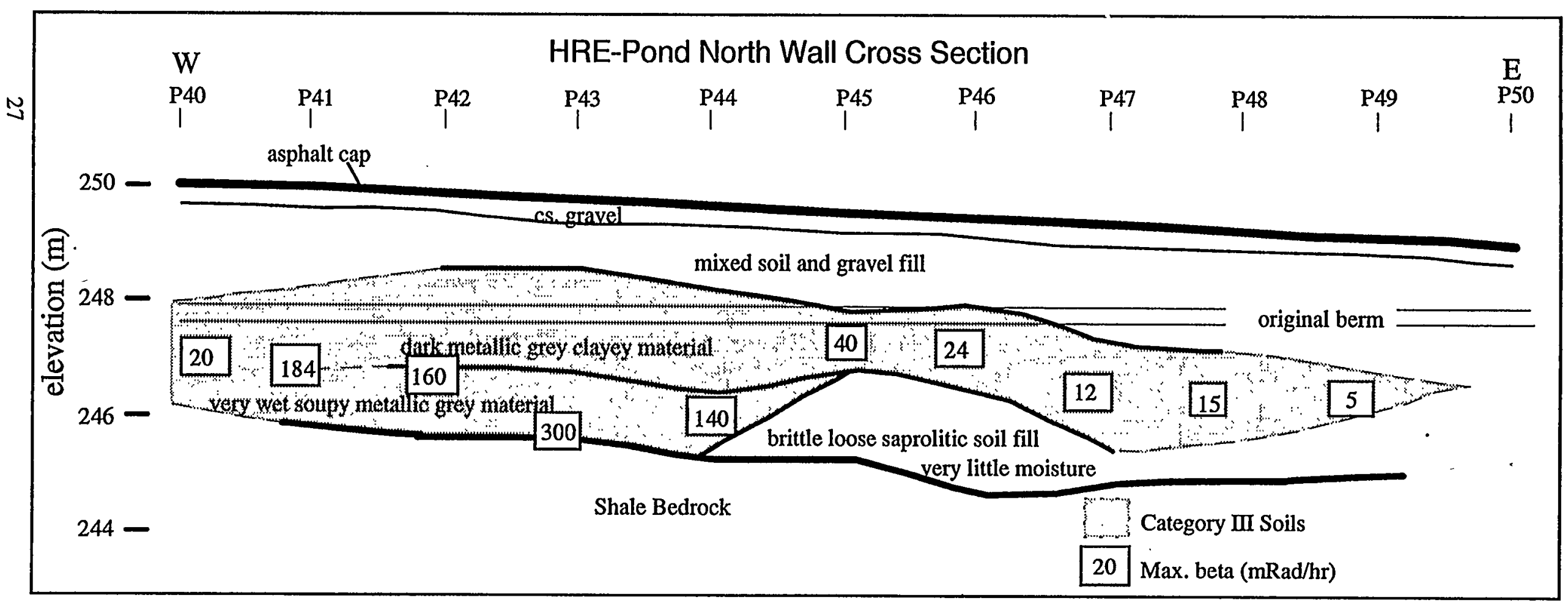

Figure 8. Geologic cross sections showing soil characteristics and contaminant distribution. 


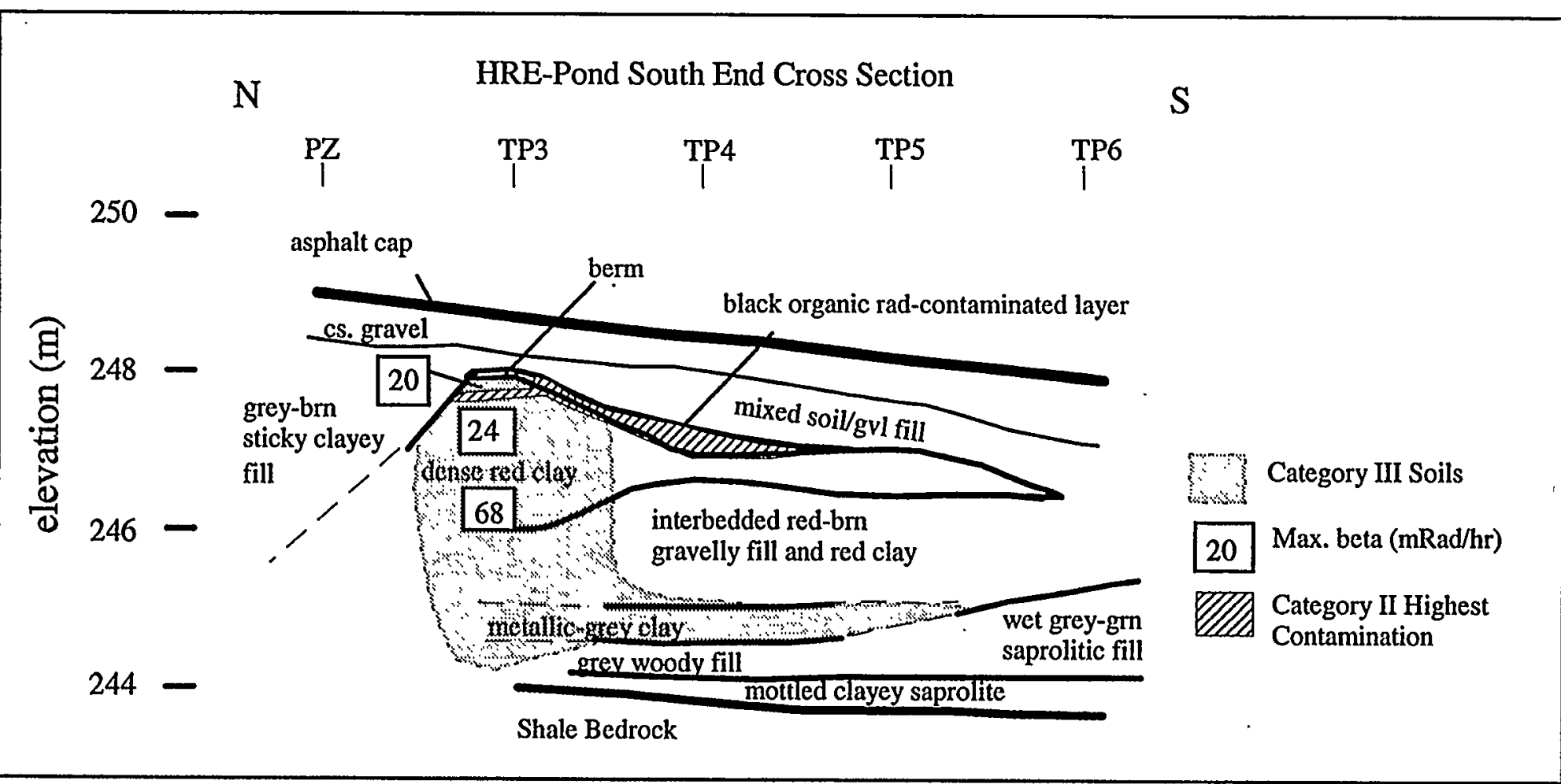

Figure 8 (cont.). Geologic cross sections showing soil characteristics and contaminant distribution. 


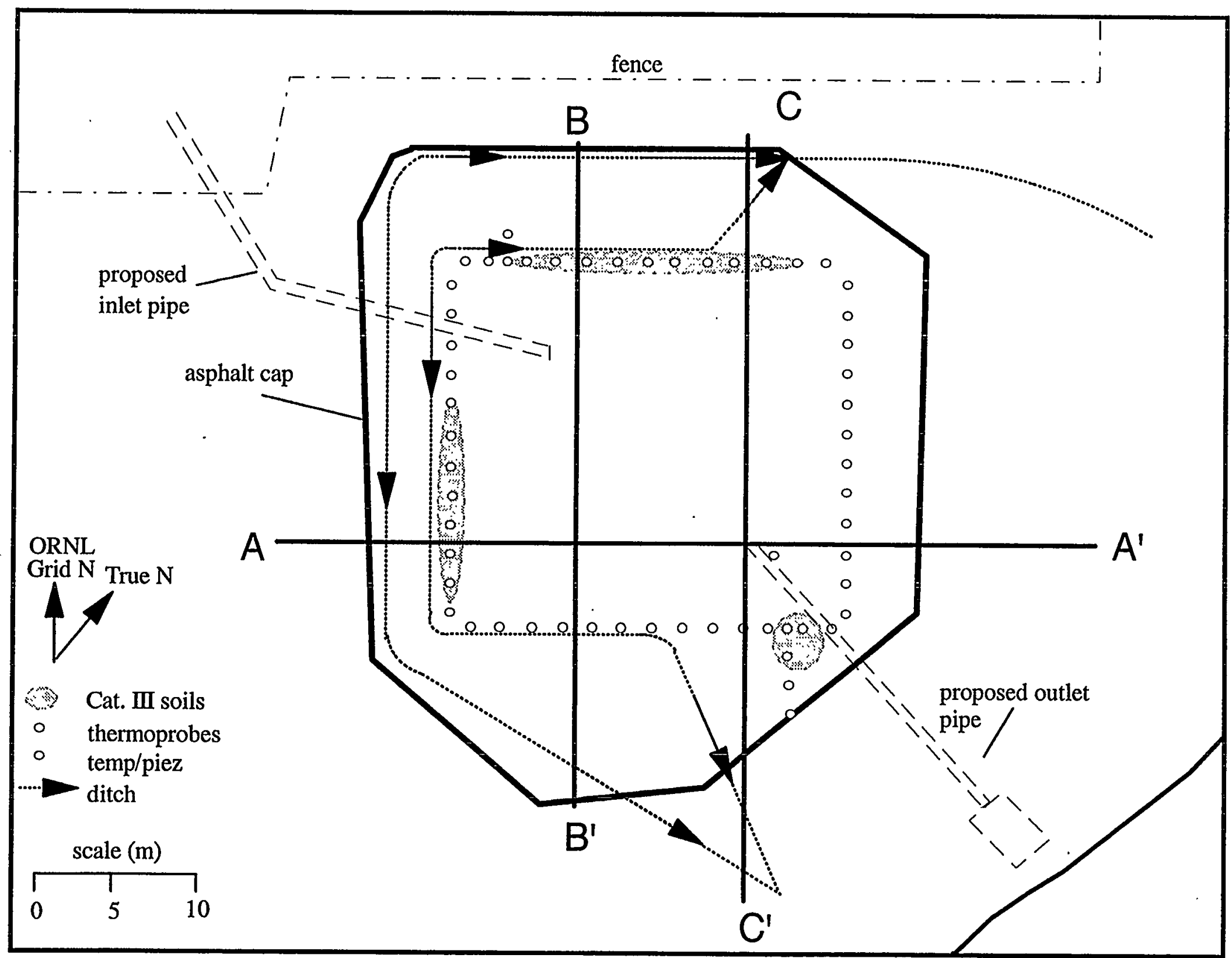

Figure 9. Areal distribution of highly-contaminated soils and proposed configuration of the original impoundment. Actual configuration is not known, particularly with respect to pipe locations. Cross section locations for figure 11 are shown. 

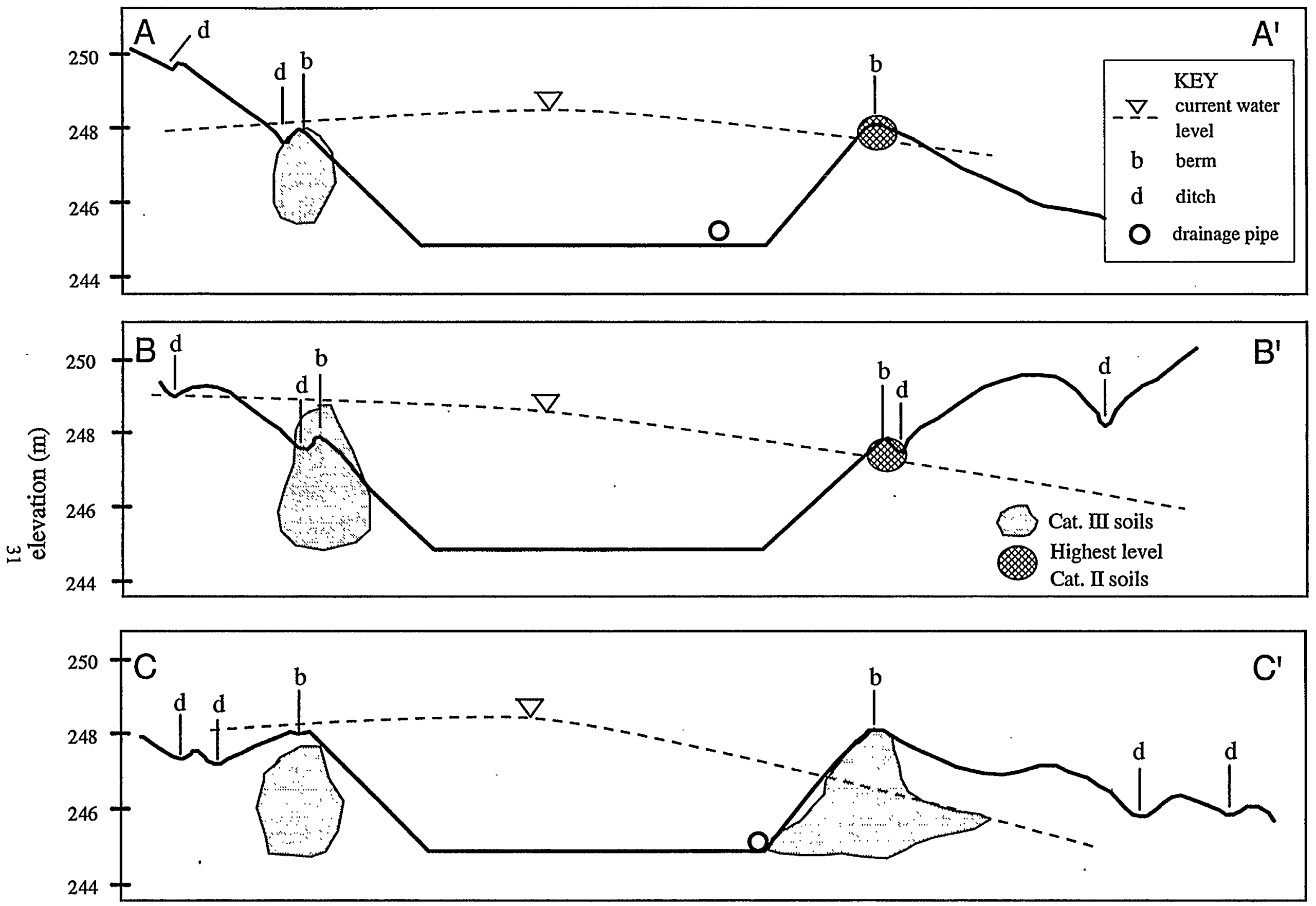

Figure 10. Cross sections showing the contaminant distribution and pre-barrier water table relative to the impoundment structure as represented in the original construction drawings. See Figure 10 for cross section locations. 


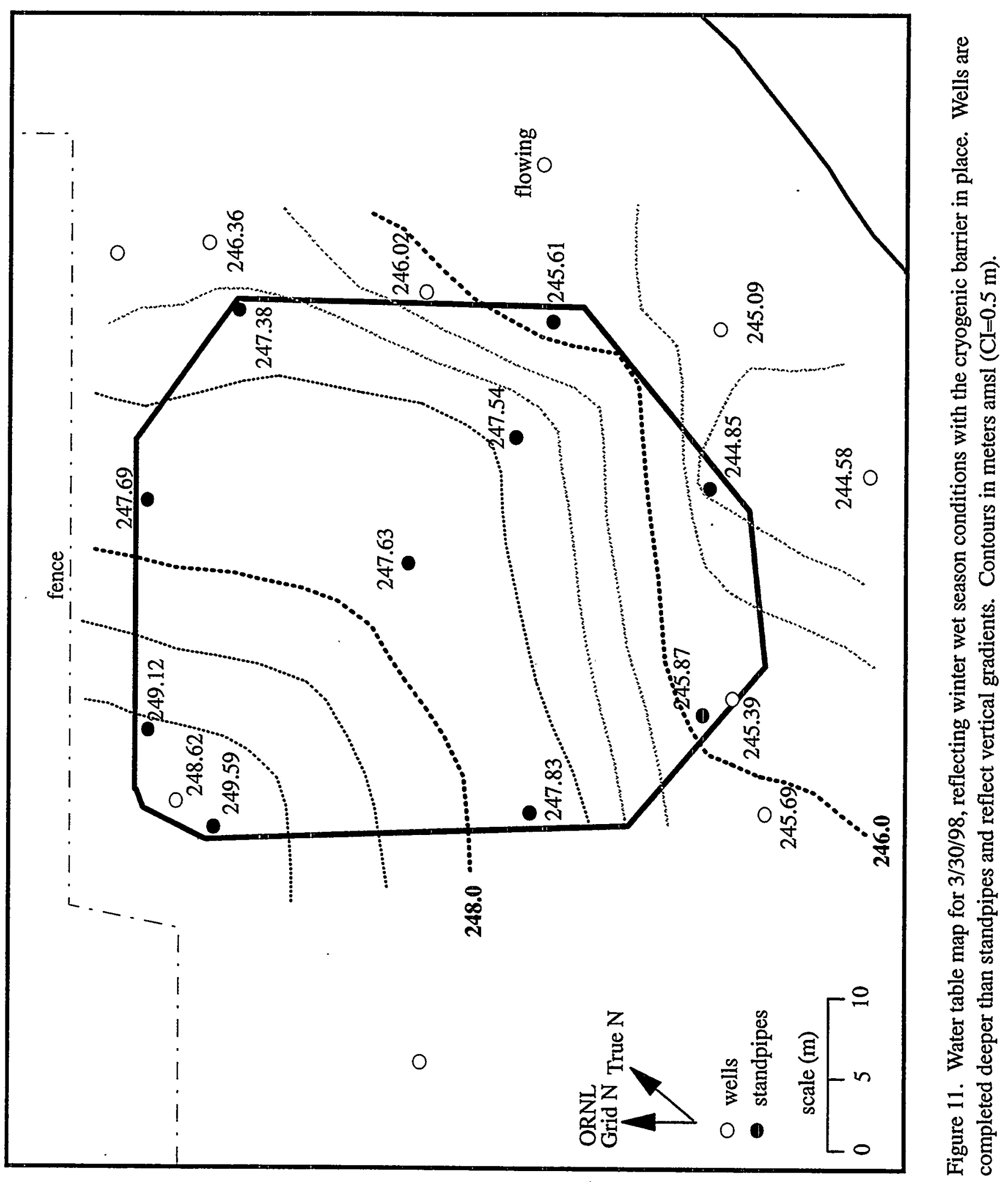




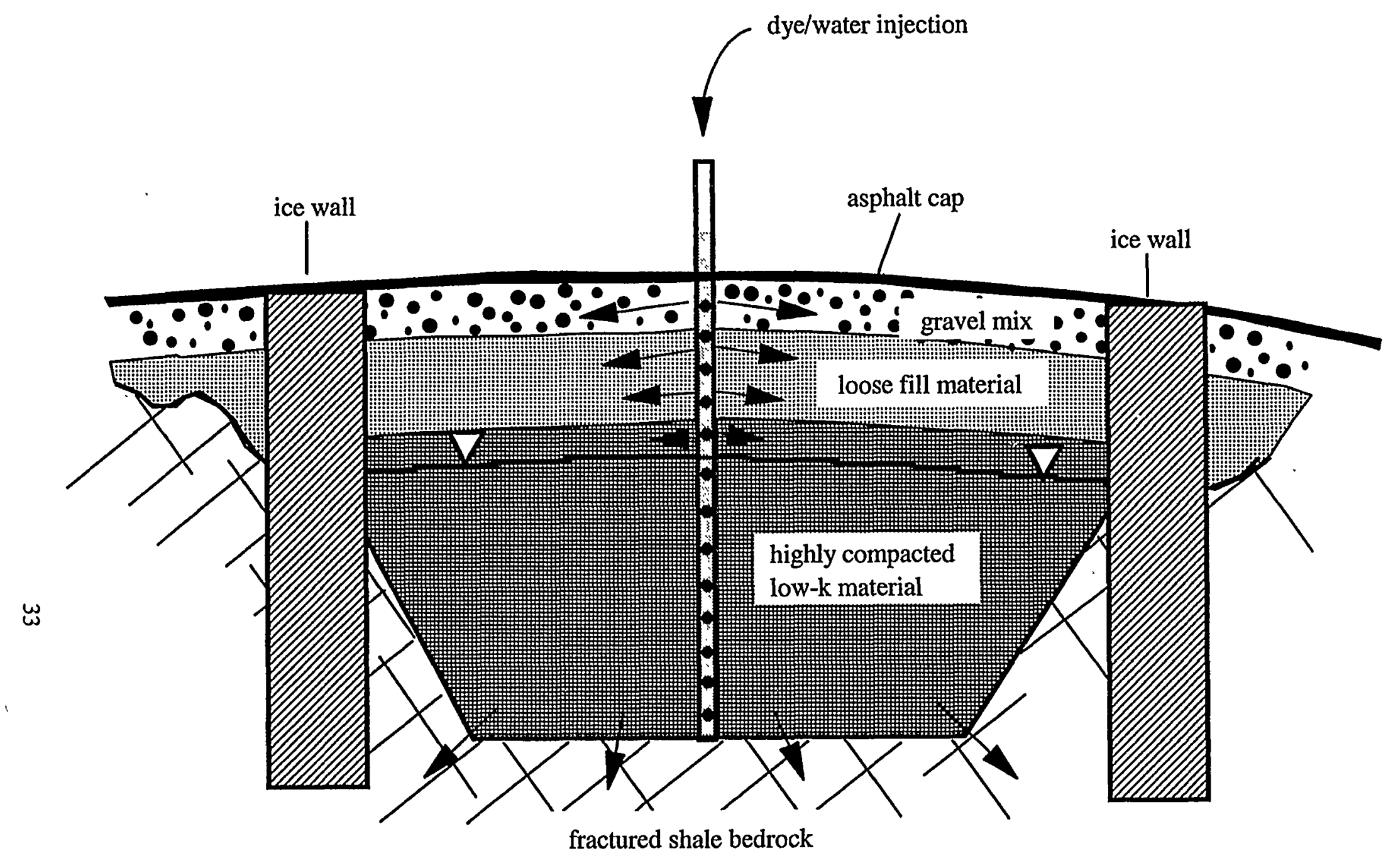

Figure 12. Due to permeability contrasts between the various materials covering the original impoundment, it is likely that the water level in the standpipe is not representative of the water table once it drops into the low-k region. Water added to the standpipe is likely to move out quickly into the higher permeability fill and gravel material, but will take much longer to reach equilibrium with the surrounding groundwater once the level in the standpipe drops below the high- $\mathrm{k}$ fill material. Because the bottom of the impoundment is not sealed, water can slowly seep through fractures in the bedrock over time. 


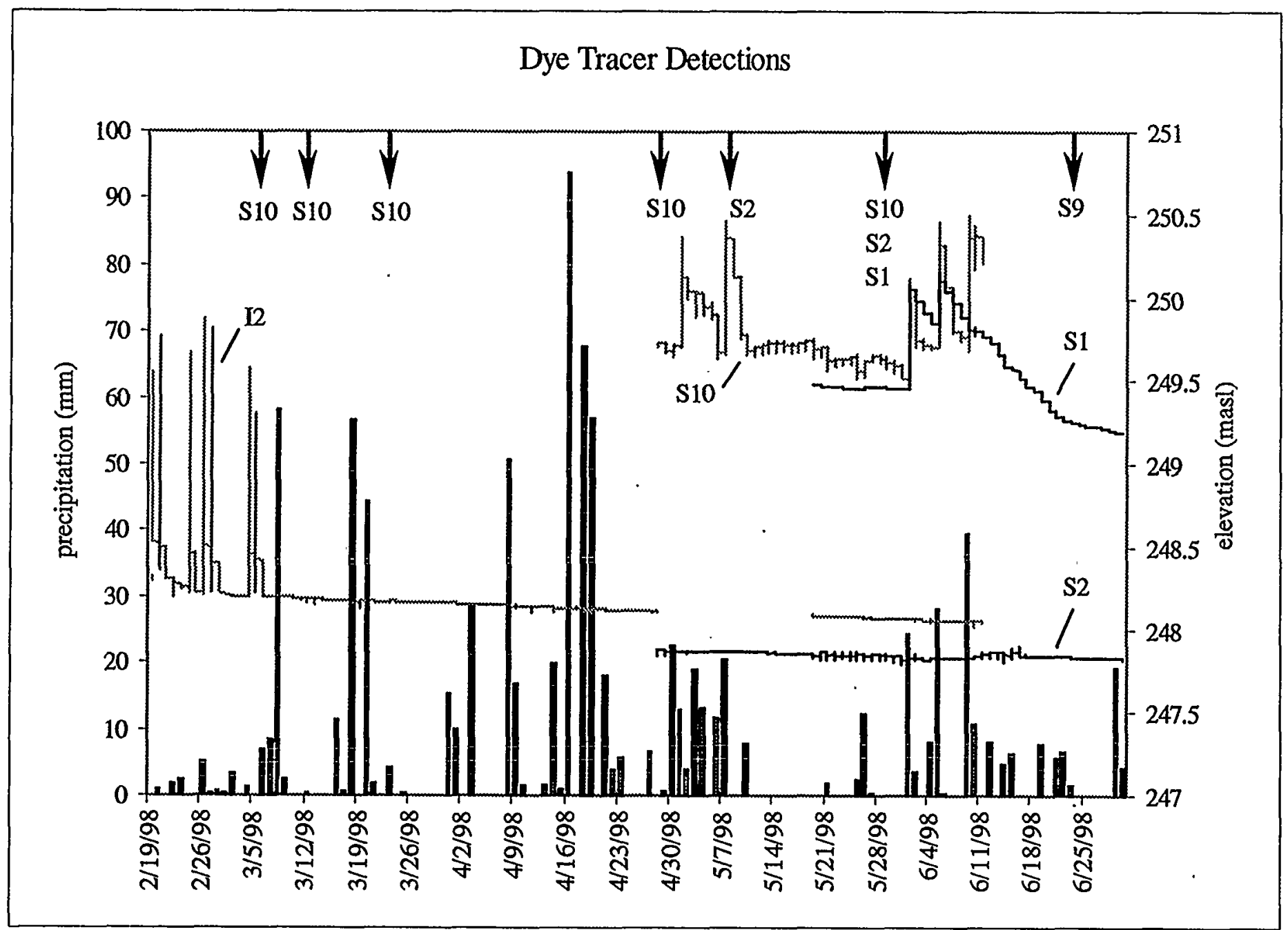

Figure 13. Composite graph showing daily precipitation, water levels in the center standpipe (I2) and the standpipes at the northwest corner of the HRE Pond, and dates and locations of dye tracer detections (arrows). 


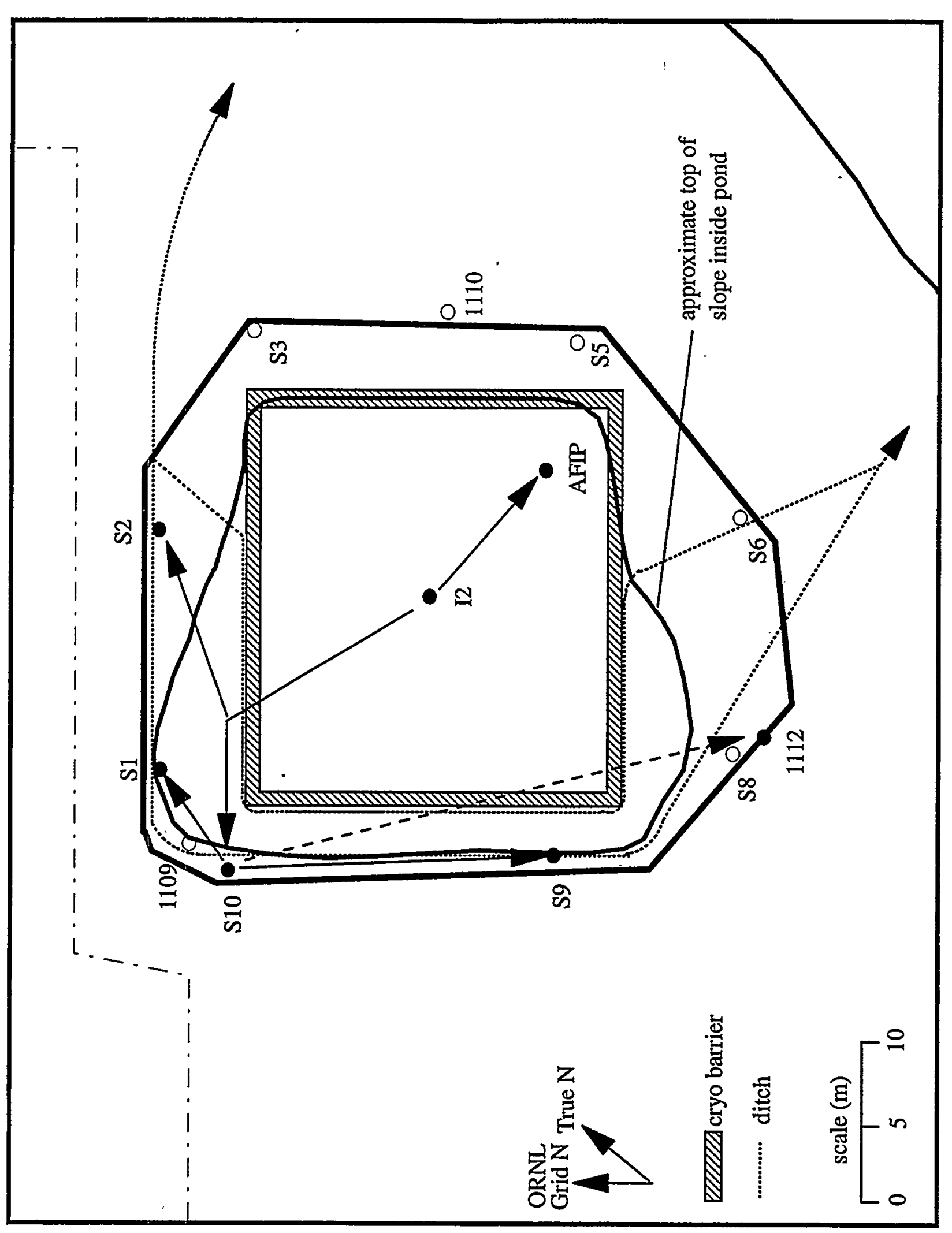

ఫ్ర్జ

옹

\&

글 중

틀

号 令

흘 흉

흉잉

.엉

品号

롱릉

율

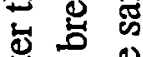

幽

인ㅇㅇ

욜 퐁

.

过

.

ষ 웡

可

\&

む)

中

.

일

造

埚

융

क् 运

뉸 을

$\pm . \Xi$

훙ㅁำ

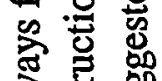

㤩骂

䒕

옹 율

造 苛

氙 苛

综兽

논

해동 
Table 1. Well Construction Information

\begin{tabular}{|c|c|c|c|c|c|}
\hline Well ID & Easting & Northing & Ground Elevation & Measuring Point & Depth \\
\hline I2 & 31475.08 & 18585.19 & 249.49 & 250.66 & 5.42 \\
S1 & 31433.45 & 18641.80 & 250.76 & 251.99 & 4.60 \\
S2 & 31487.11 & 18640.32 & 249.28 & 250.50 & 4.16 \\
S3 & 31532.40 & 18622.46 & 247.97 & 249.16 & 4.60 \\
S5 & 31531.11 & 18556.26 & 247.81 & 249.02 & 5.07 \\
S6 & 31496.69 & 18522.25 & 247.49 & 248.70 & 5.44 \\
S8 & 31438.51 & 18519.74 & 247.87 & 249.08 & 5.46 \\
S9 & 31417.97 & 18561.36 & 249.58 & 250.79 & 3.30 \\
S10 & 31416.20 & 18631.13 & 250.88 & 252.16 & 3.28 \\
0670 & 31450.94 & 18697.47 & 251.77 & 252.36 & 12.20 \\
0671 & 31365.71 & 18581.74 & 250.22 & 250.83 & 10.44 \\
0672 & 31420.23 & 18508.96 & 247.64 & 248.40 & 7.20 \\
0673 & 31561.94 & 18556.40 & 245.97 & 246.42 & 8.48 \\
0674 & 31542.63 & 18647.27 & 246.67 & 247.54 & 5.32 \\
0675 & 31493.50 & 18486.97 & 246.35 & 246.76 & 6.95 \\
0898 & 31544.78 & 18627.49 & 246.94 & 247.43 & 3.81 \\
1109 & 31422.87 & 18634.87 & 250.91 & 252.07 & 9.05 \\
1110 & 31533.62 & 18581.39 & 247.92 & 248.63 & 7.59 \\
1111 & 31525.86 & 18518.64 & 246.31 & 247.13 & 7.53 \\
1112 & 31444.65 & 18515.45 & 247.83 & 248.75 & 7.53 \\
AFIP & 31502.00 & 18562.00 & 248.79 & 246.73 & -- \\
\hline \hline
\end{tabular}




\section{INTERNAL DISTRIBUTION}

1. J. H. Cushman

2. D. E. Fowler

3. R. L. Graham

4. S. G. Hildebrand

5. G. K. Jacobs

6. P. Kanciruk

7. J. M. Loar
8. G. R. Moline

9. T.E. Myrick

10. D. E. Reichle

11. Central Research Library

12-14. ESD Library

15-16. Laboratory Records Department

17. Laboratory Records, ORNL-RC

\section{EXTERNAL DISTRIBUTION}

18. E. G. Cumesty, Assistant Manager for Laboratories and Site Manager, Department of Energy, Oak Ridge National Laboratory, P.O. Box 2008, Oak Ridge, TN 37831-6269

19. Gareth J. Davies, Carnbrian Groundwater Company, 109 Dixie Lane, Oak Ridge, TN 37830

20. Jerry Elwood, Acting Director, Environmental Sciences Division, ER-74, Department of Energy, 19901 Germantown Road, Germantown, MD 20874

21. J. P. Giesy, College of Natural Science, Department of Zoology, Michigan State University, 203 Natural Science Building, East Lansing, MI 48824-1115

22-27. Mike Harper, Bechtel-Jacobs Company LLC, P.O. Box 2669, Oak Ridge, TN 37831.

28. A. A. Lucier, National Council of the Paper Industry For Air and Stream Improvement, Inc., P.O. Box 13318, Research Triangle Park, NC 27709-3318

29. Michael C. MacCracken, National Assessment Coordination Office, 400 Virginia Avenue, S.W., Suite 750, Washington, DC 20024

30-35. Elizabeth Phillips, Department of Energy, 55 Jefferson Avenue, Oak Ridge, TN 37830

36. L. Robinson, Director, Environmental Sciences Institute, Florida A\&M University, Science Research Facility, 1520 S. Bronough Street, Tallahassee, FL 32307

37. Steve Rock, U.S. Environmental Protection Agency, 26 W. Martin Luther King Drive, Cincinnati, Ohio 45268

38. John Sebastian, TDEC, 761 Emory Valley Road, Oak Ridge, TN 37830

39. J. M. Tiedje, University Distinguished Professor and Director, Michigan State University, 540 Plant and Soil Sciences Building, East Lansing, MI 48824

40. Ed Yarmak, Arctic Foundations, Incorporated, 5621 Arctic Boulevard Anchorage, Alaska 99518-1667 